\title{
Affonso de Taunay e as duas versões do mapa de D. Luis de Céspedes Xeria (1628)
}

Affonso de Taunay and the two versions of the map of $d$. Luis de Céspedes Xeria (1628)

\section{JORGE PIMENTEL CINTRA'}

Universidade de São Paulo / São Paulo, SP, Brasil

\section{JOSÉ ROGÉRIO BEIER²}

Universidade de São Paulo / São Paulo, SP, Brasil

\section{LUCAS MONTALVÃO RABELO 3}

Universidade de São Paulo / São Paulo, SP, Brasil

RESUMO: Este trabalho tem como objetivo aprofundar o estudo do mapa da viagem de D. Luis de Céspedes Xeria da vila de São Paulo de Piratininga a Ciudad Real de Guayrá, na Província do Paraguai, em 1628. Para tanto, recorremos a fontes primárias como os manuscritos da Coleção De Angelis, mantidos na Biblioteca Nacional no Rio de Janeiro, bem como aos manuscritos do Archivo General de Indias, em Sevilha, incluindo a ampla documentação escrita e sobretudo as duas versões disponíveis do documento cartográfico produzido por Céspedes Xeria em 1628. Em seguida comparamos a cópia encomendada por Affonso d'Escragnolle Taunay em 1917 com ambos originais seiscentistas remanescentes, aferindo-se a fidelidade dessa cópia com um dos originais. Analisamos ainda as representações cartográficas dos povoamentos representados no mapa, que em 1938 suscitaram discussões públicas entre Taunay e Benedito Carneiro Bastos Barreto, o Belmonte, concluindo que todos são símbolos cartográficos ou ícones padronizados em vez de representações baseadas na aparência dos edifícios tal como eram quando foram visitados por Céspedes Xeria na primeira metade do século XVII. Durante este processo distinguimos dois momentos do historiador Taunay: o primeiro revela sua preocupação com a fidelidade ao
1. Professor do Museu Paulista da Universidade de São Paulo (USP)), atuando principalmente na Curadoria das Coleções Cartográficas. Doutor em Engenharia Civil e Urbanismo pela Universidade de São Paulo (USP). E-mail: <jpcintra@ usp.br>.

2. Doutorando em História Econômica, mestre em História Social, bacharel e licenciado em História pela Faculdade de Filosofia, Letras e Ciências Humanas (FFLCH-USP). E-mail: <rogerio.beier@usp.br>.

3. Doutorando em História Social pela Faculdade de Filosofia, Letras e Ciências Humanas (FFLCH-USP), mestre em História Social pela Universidade Federal do Amazonas (UFAM), bacharel e licenciado em História pela Universidade Federal do Paraná (UFPR). E-mail: <lucas.montalvao@ usp.br>. 
copiar documentos, e o segundo, a plasticidade de interpretação na análise e utilização desses documentos.

PALAVRAS-CHAVE: Céspedes Xeria; Affonso d'Escragnolle Taunay; Mapa do Rio Tietê; Casa da Câmara e Cadeia; São Paulo.

ABSTRACT: The following paper aims to deepen the studies about the map of the travel made by D. Luis de Céspedes Xeria from the town of São Paulo de Piratininga to the Ciudad Real de Guayrá, in the Province of Paraguay, in 1628. For this, we used primary sources such as the manuscripts of the De Angelis Collection, kept in the National Library in Rio de Janeiro, as well as the manuscripts of the Archivo General de Indias, in Seville, including the extensive written documentation and, specially, the two available versions of the cartographic document made by Céspedes Xeria, in 1628. We then compared the copy commissioned by Affonso d'Escragnolle Taunay, in 1917, with both of the seventeenth-century remaining originals, concluding for its fidelity to one of them. In addition, we analyzed the cartographic representations of the settlements represented in the map, which aroused, in 1938, public discussions between Taunay and Benedito Carneiro Bastos Barreto, also known as Belmonte, coming up to the conclusion that all of them are cartographic symbols or standardized icons rather than representations based on the appearance of the buildings such as they were when they were visited by Céspedes Xeria in the first half of the seventeenth century. During this process it was possible to distinguish two different moments of the historian Taunay: the first, his concerning for fidelity in copying documents; and the second, a plasticity of interpretation in the moment of analyze and use these same documents.

KEYWORDS: Céspedes Xeria; Affonso d'Escragnolle Taunay; Map of the Tiete River; House of Council and Jail; São Paulo. 
Aproxima-se o bicentenário de nossa Independência e acaba de completarse o centenário da publicação de uma cópia do Mapa del río Ayembí (actual Tieté) y del Paraná, con sus afluentes, que recorrió Luis de Céspedes Jería, gobernador del Paraguay, al entrar en su jurisdicción desde Brasil. Torna-se, pois, oportuno seu estudo mais aprofundado, também pelo fato de alguns trabalhos recentes - ao não levarem em conta algumas fontes primárias (entre elas uma segunda versão desse mapa) - ficaram na dúvida se Affonso d'Escragnolle Taunay (1876-1958) ou o cartógrafo que trabalhou para ele teriam modificado esse documento cartográfico. ${ }^{4}$

Colocações semelhantes não são novidades na historiografia paulista. Nos fins do século XIX, Cândido Mendes de Almeida atribuiu a Frei Gaspar da Madre de Deus forjar um documento a respeito da aclamação de Amador Bueno para construir um passado glorioso e independentista para São Paulo. Taunay, em defesa do historiador beneditino, encontrou em 1915 uma patente comprovando a fidelidade com que este transcreveu sua fonte, ${ }^{5}$ o que mostra seu apreço pelos documentos, ao elogiar a fidelidade do historiador beneditino.

Agora é o momento de trazer à baila uma cópia duplicada, também manuscrita e com mesma data, do mapa de Céspedes Xeria existente no Archivo General de Indias, ${ }^{6}$ que comprova que o então diretor do Museu Paulista não fez nem mandou fazer mudanças. $\bigcirc$ estudo mostra, entre outras conclusões, como a cartografia encomendada por Taunay reproduz com perfeição todos os detalhes do segundo mapa feito por Céspedes três séculos antes.

\section{AFFONSO DE TAUNAY E O MAPA DE D. LUIS DE CÉSPEDES XERIA}

Para entender a relação de Taunay com esse mapa é importante reconstituir brevemente sua trajetória profissional até sua nomeação como diretor do Museu Paulista em 1917, mesmo ano em que solicitou uma cópia do mapa em estudo.?

Affonso Teixeira d'Escragnolle Taunay nasceu na cidade do Desterro latual Florianópolis) em 1876, tendo se mudado com sua família para o Rio de Janeiro alguns meses após seu nascimento. Foi na antiga capital do Brasil que iniciou seus estudos no Colégio D. Pedro II e formou-se em 1900 como engenheiro-civil na Escola Politécnica daquela cidade. Iniciou sua carreira profissional em São Paulo, onde por indicação de Augusto Carlos da Silva Teles ${ }^{8}$ foi contratado a 9 de janeiro
4. Cavenaghi (2011, p. 90) considera ter havido alterações estruturais na cópia encomendada por Taunay, o que poderia ter ocorrido por iniciativa direta deste ou do cartógrafo que trabalhou a suas ordens. Já Biason (2015), dando um passo adiante, considera que a mudança estrutural foi feita pelo cartógrafo. Com base nesses dois trabalhos vem sendo aceito que Taunay fez cópias modificadas para seus propósitos.

5. Cf. o prefácio de Taunay à Memória para a bistória da Capitania de São Vicente, de Frei Gaspar da Madre de Deus (1953, p. 21-22)

6. Essa cópia é caracterizada como duplicado por esse Archivo, querendo indicar a identidade substancial com o outro exemplar.

7. Os dados do breve perfil biográfico aqui apresentados foram extraídos principalmente de Matos (1977).

8. Este professor catedrático da Escola Politécnica foi casado com Eugenia Teixeira Leite, irmã de Cristina Teixeira Leite, mãe de Taunay. Cf. GENi (2018). 
9. Para entender a cronologia acadêmica de Taunay é preciso considerar que o ano escolar, seguindo o modelo europeu, começava em setembro e terminava em maio/junho. Taunay portanto ingressou no meio do ano acadêmico de 1899-1900, antes de concluir o curso na Escola Politécnica do Rio de Janeiro, e aparentemente voltou algumas vezes para finalizar trabalhos ou exames pendentes, estando documentadas algumas solicitações de afastamento junto à administração da Escola

10. Segundo a historiadora Karina Anhezini, com o início dos cursos de Filosofia e Letras em 1911, a Faculdade Livre de Filosofia e Letras de São Bento se tornou a primeira faculdade livre de filosofia do Brasil. Sobre a participação de Taunay no corpo docente da faculdade e seu discurso inaugural no curso de história universal em maio de 1911, cf. Anhezini (2009).

11. Para um estudo sobre os intercâmbios entre Taunay e sua rede de sociabilidade em torno da escrita da História, cf. Anhezini (2003).

12. Taunay (1938, p. 8). O tom da redação de Taunay passa a impressão de tratarse até mesmo de uma conversa ou correspondência pessoal com Pastells.

13. Pastells (1912). de 1899 como preparador dos laboratórios de química na Escola Politécnica paulista. ${ }^{9}$ Nessa escola Taunay foi lente substituto da cadeira de física experimental e noções de ciências naturais (botânica e zoologia) a partir de 1904, sendo efetivado como lente catedrático das cadeiras da área de física, que incluíam as noções de ciências naturais, em 1911.

Paralelamente, Taunay nutria profundo interesse pela história do Brasil, tendo sido discípulo de Capistrano de Abreu no Colégio D. Pedro II, professor e amigo com quem manteve ativa e profícua correspondência por décadas. Sua proximidade com os beneditinos, que desde cedo haviam notado seu tino para a história, rendeuthe um convite para lecionar a disciplina de história universal no Ginásio de São Bento, em 1903. Oito anos mais tarde o abade do mosteiro beneditino, D. Miguel Kruse, o convidaria para ministrar a mesma disciplina na Faculdade Livre de Filosofia e Letras de São Bento. ${ }^{10}$ Destarte, pode-se dizer que sua experiência como professor; a atuação nos institutos históricos - com a publicação de seus primeiros e importantes trabalhos na área; e a proximidade das comemorações pelo centenário da Independência do Brasil foram elementos fundamentais para que Taunay fosse nomeado "diretor em comissão" do Museu Paulista em fevereiro de 1917, em substituição ao naturalista alemão Hermann von thering. ${ }^{11}$

Em seu primeiro ano como diretor do Museu Paulista, Taunay se empenhou em inaugurar uma nova sala de exposição que fosse exclusivamente dedicada à história do Brasil e ao passado paulista (Sala A-10). Nessa sala, a cartografia era peça importante para a composição de um cenário expositivo que narrasse a história brasileira segundo suas concepções. Nesse sentido, ele buscava adquirir, por permuta ou encomenda de cópias fac-similares, toda uma documentação relacionada ao passado pátrio ou de São Paulo. Do arquivo sevilhano, de nosso interesse mais imediato, Taunay se empenhou em conseguir uma cópia fac-similar do Mapa de D. Luís de Céspedes Xeria, cuja existência naquela instituição soube pelo Reverendo Padre Pablo Pastells, como ele mesmo declara em artigo publicado na Folha da Manhã: "Quando em 1917, o eminente Pablo Pastells me assinalou a presença do mapa de Céspedes no Archivo General de Indias, em Sevilha, e mo descreveu, sofregamente o fiz copiar fac-similarmente. Dei-me logo pressa em divulgar esse documento preciosíssimo". ${ }^{12}$ Além disso, cabe lembrar que o primeiro tomo de sua monumental História da Companhia de Jesus ${ }^{13}$ iá havia sido publicada cinco anos antes.

Para se ter uma ideia do trabalho realizado por Taunay, apenas em seu primeiro ano como diretor foram levantadas 46 cartas para a inauguração da sala A-10. Segundo o Correio Paulistano de 24 de dezembro daquele ano, a inauguração da nova sala ocorreu em 25 de dezembro, em que foram expostas 29 cartas quinhentistas, 16 seiscentistas e 9 setecentistas, ${ }^{14}$ das quais 39 referiam- 
se à cartografia sul-americana e brasileira e apenas sete à paulista. Ainda segundo o texto publicado no periódico, a intenção, nesse primeiro momento, era mostrar "a evolução da geografia do nosso continente, desde o mappa de Juan de la Cosa, datado do anno pronto da descoberta do Brasil, até o das "Côrtes", em 1750, carta oficial da demarcação dos territórios das corôas de Portugal e Hespanha, em virtude do tratado de Madrid". ${ }^{15}$

A cópia do mapa de Céspedes Xeria foi acertada por correspondência com Santiago Montero Díaz, um copista já bastante experimentado que trabalhava no Archivo General de Indias. ${ }^{16}$ Montero Díaz não copiou apenas o mapa, mas também toda a documentação que dizia respeito a essa peça cartográfica, assim como o material textual referente a Céspedes Xeria.

Na correspondência trocada entre Taunay e Montero Díaz, vê-se a especial atenção que Taunay solicitava em relação à fidelidade da cópia a ser realizada. A este respeito, Montero Díaz informava a Taunay, em carta datada de 13 de agosto de 1917, que a cópia já estava em andamento conforme seu pedido, e que:

En conformidad de lo que el señor me dice de que desea una copia exacta del mapa de don Luis de Cespedes Xeria con su tamaño y colores naturales, reproducción exacta de un delineante cartográfico, le comunico que queda haciéndose y que cuando esté terminado se lo enviaré. ${ }^{17}$

Em resposta a esta carta, Taunay voltava a insistir na questão da exatidão e fidelidade da cópia a ser feita, como se pode observar na carta enviada por ele em 13 de setembro de 1917:

Já desanimara de receber resposta sua quando hoje tive o prazer de ler sua carta. Como já tive a occasião de the escrever, desisti de mandar fazer photographia do mappa de D. Luiz Cespedes; o que desejo é uma reprodução exacta, fiel, dessa carta. ${ }^{18}$

Ao concluir a cópia, Montero Díaz enviou nova correspondência a Taunay, datada de $1^{\circ}$ de outubro de 1917, informando-lhe que havia concluído o trabalho e remetido o mapa ao Brasil, dando conta ainda do valor que cobrara pelos serviços realizados.

Con esta fecha le remito por correo certificado y en paquete separado la copia del mapa de don Luis de Cespedes Xeria que me pidió en su carta de 19 de junio del presente año.
14. Vale notar que os números indicados pelo jornal contêm um erro de impressão na informação publicada, pois a soma de 29, 16 e 9 resulta em 54 , e não nas $46(39+7)$ cartas que Taunay levantou para a inauguração da sala A-10, como informado.

15. Taunay (1917, p. 2).

16. À época em que Taunay encomenda a cópia do Mapa de Céspedes Xeria, Montero Díaz já havia realizado uma série de cópias, transcrições e pesquisas para outros museus, instituições e particulares. Segundo DíazTrechuelo (1997, p. 61), o "infatigable" Santiago Montero já se encontrava no Archivo General de Indias (AGI) fazendo "investigaciones por conta ajena", e que "conocía el Archivo al dedillo". Rey (2013, p. 132) confirma a atuação de Montero Díaz como copista em Sevilha, informando que na década de 1920 ele oferecera seus serviços à chamada "Missão Torre Revello" (missão argentina liderada por José Torre Revello realizada entre 1918-1935, visando transcrever documentos americanos mantidos em diferentes arquivos espanhóis); ele trabalhava a meia jornada na etapa sevilhana do projeto, ajudando a transcrever a quarta seção da obra Archivo General de Indias: papeles de justicia de Indias. Por fim, cabe destacar que a revista The Americas publicou uma série de artigos (v. 40, n. 4; v. 41, n. 3 ; v. 43 , n. 4 ; v. 46 , n. 4) intitulados "Archival notes of Santiago Montero Díaz from the Archivo General de Indias", descrevendo a vasta documentação americana do período colonial mantidos no AGI. Cf. Archival... (1985). 
17. Carta de Santiago Montero Díaz a Affonso d'Escragnolle Taunay, de 13 de agosto de 1917. São Paulo: Arquivo Permanente do Museu Paulista/Fundo Museu Paulista (APMP/ FMP), 1917. Pasta 104.

18. Carta de Affonso d'Escragnolle Taunay a Santiago Montero Díaz, de 13 de setembro de 1917. São Paulo: APMP/FMP, 1917. Pasta 104.

19. Carta de Santiago Montero Díaz a Affonso d'Escragnolle Taunay, de $1^{\circ}$ de outubro de 1917. São Paulo: APMP/FMP, 1917. Pasta 104.

20. Taunay (1917, p. 2).

21. Principalmente os artigos publicados nos dias 23 e 27 de abril e os de 14 e 23 de maio de 1919 (Taunay, 1919a, 1919b, 1919c, 1919d).

22. Os artigos foram revisados e ampliados, segundo Taunay, a partir da obtenção de nova documentação. Seu trabalho $\mathrm{Na}$ era das bandeiras: estudos de bistória colonial paulista foi reeditado como livro dois anos mais tarde, no âmbito das comemorações do centenário da Independência do Brasil. Cf. Taunay (1920, 1922b).

23. Por outro lado, Taunay manteve a Revista do Museu Paulista dedicada à História Natural, em que ele mesmo publicou diversos artigos. Atualizamos a grafia, Annaes, para Anais. Cf. Anais do Museu Paulista (1922, p. 180-270).
Se ha tardado en copiarlo algún tiempo más del que yo le dije en mi carta de 22 de febrero pero se ha hecho con todo esmero y en copia exacta del original en tamaño, dibujo y colores, hasta el extremo de que los trazos de letras que en el original estén muy gruesos por haberse corrido la tinta, se han puesto iguales en la copia y se lo advierte para que no se crea que ha sido falta del copista.

Respecto al pago, pongo con esta misma fecha en circulación una letra a su cargo y ocho días vista por valor del importe de la copia del mapa, 200 pesetas, que espero será de su conformidad. ${ }^{19}$

Por este trecho, vê-se que para atender o pedido de Taunay chegou ao extremo de reproduzir os traços mais grossos do mapa, feitos acidentalmente no original em decorrência de escorrimento da tinta. Quanto ao valor pago pelos serviços de Montero Díaz, as duzentas pesetas equivaliam a 178 mil réis (178\$000), que foram pagas em duas remessas de cem pesetas.

Tão logo as cópias dessa documentação chegaram a suas mãos, Taunay passou a divulgá-las. A inauguração da sala A-10 foi uma das iniciativas nesse sentido, sendo o mapa de Céspedes Xeria um dos destaques da exposição, como fez questão de apontar o já mencionado texto publicado no jornal Correio Paulistano. ${ }^{20}$

Além de expor a cópia fac-similar da carta que mandara fazer na Espanha, Taunay também passou a divulgar a história de Céspedes Xeria e de seu "mapparoteiro" através de uma série de artigos que publicou no Correio Paulistano entre 1917 e 1919.21 Posteriormente, esses artigos foram reunidos e publicados na Revista do Instituto Histórico e Geográfico Brasileiro sob o título de Na era das bandeiras. ${ }^{22}$ Mais que isso, nas comemorações do centenário da Independência do Brasil, Taunay publicou toda a documentação que já havia reunido e transcrito sobre esse tema no primeiro tomo da nova revista que criara centrada exclusivamente em história, os Anais do Museu Paulista. ${ }^{23}$

Por fim, vale observar que, se por um lado Taunay se empenhava em obter cópias fiéis da documentação cartográfica que mandara levantar nos mais distintos acervos, por outro, deu-se grande liberdade para organizar a nova sala A-10 como concebia e interpretava a história paulista e nacional. Nesse sentido, convém apontar que o cenário expositivo do novo espaço contava com, além dos mapas que ele mandara copiar - todos emoldurados e expostos nas paredes -, outros elementos como documentos textuais, quadros, retratos e efígies de personalidades que, segundo sua concepção histórica, contribuíram para a formação do Brasil. Assim, expunham-se ao lado das cartas que pretendiam mostrar a "evolução da geografia de nosso continente", as efígies de Alexandre de Gusmão, tido por 
Taunay como "o primeiro delimitador diplomático da fronteira nacional", e do Barão do Rio Branco, "o fixador das fronteiras definitivas da confederação brasileira". Junto a esses também expôs um retrato do bandeirante Domingos Jorge Velho, destruidor do Quilombo dos Palmares, entremeado pelos retratos do imperador, D. Pedro I e do patriarca da Independência, José Bonifácio de Andrada e Silva. Havia ainda quadros de personalidades do quinhentismo paulista, tais como Martim Afonso de Souza, o fundador de São Vicente e donatário da capitania homônima, e do Padre José de Anchieta, um dos fundadores do colégio jesuítico em Piratininga que deu origem à vila de São Paulo em 1560.

Portanto, não é equivocado afirmar que a atuação de Affonso de Taunay na formação da coleção cartográfica do Museu Paulista nos primeiros anos de sua gestão foi, juntamente com a aquisição de coleções textuais e iconográficas, muito importante para que ele conseguisse engendrar a trama de uma narrativa histórica nacional na qual os paulistas eram tidos como protagonistas. Essa coleção também celebrava os feitos dos antepassados da elite cafeeira paulista que, desde os primeiros anos da República, estava no controle do poder político do Brasil. Não por acaso, foi justamente essa elite quem deu carta branca e "largos créditos" a Taunay para que ele levasse adiante seu projeto de transformação do Museu em uma instituição devotada às histórias paulista e brasileira.

Por outro lado, vale a pena destacar desde já um ponto: o olhar crítico para o modo como Taunay formou essa coleção cartográfica aponta para, entre outros aspectos, sua grande preocupação com os documentos que mandara copiar em fac-símile, por manter a maior fidelidade possível, até mesmo nos mínimos detalhes, reproduzindo inclusive rasuras ou manchas dos originais. Tal cuidado na transcrição dos documentos textuais sob orientação de Taunay já havia sido observado pelos trabalhos de Ana Cláudia Brefe ${ }^{24}$ e Karina Anhezini, ${ }^{25}$ de modo que essas autoras aproximaram o antigo diretor do Museu Paulista da escola metódica de historiadores, com forte influência dos franceses Langlois e Seignobos.

É de fato importante fazer a análise crítica do modo como Taunay selecionou, organizou e divulgou o acervo, mas é preciso ao mesmo tempo ter o cuidado na análise heurística da documentação levantada pelos envolvidos na cópia fac-similar, a fim de que se evitem afirmações que coloquem em questão a idoneidade, tanto dos pesquisadores (Affonso de Taunay) como das instituições envolvidas (Archivo General de Indias e Museu Paulista).

Como se destacou até aqui, a organização dos documentos reunidos por Taunay para a inauguração da sala A-10 está de fato alinhada com sua concepção do como fazer história e, ao mesmo tempo, com a visão que tinha da história nacional. Na composição do cenário expositivo dessa sala, buscou destacar o 
26. Anais do Museu Paulista (1922, p. 182-186 e 230233). Os originais encontram-se no AGI, Estante 74, Caixa 4, Dossiê 15 (74-4-15), estão disponíveis digitalmente em AGI, CHARCAS 30 R.1, N.1, imagens 1-4, além de um duplicado a seguir, nas imagens 5-8 e a segunda carta em CHARCAS 30 R.1, N.2, imagens 1-3.

27. Pliego faz referência a um documento ou pasta com folhas dobradas, formando uma unidade, em contraste com páginas abertas sem dobras ou pregas. Esta carta descreve cinco pliegos, embora mencione seis na relação de acontecimentos de seu governo, feita em 6 de fevereiro de 1629 em Ciudad Real e copiada em Asunción a 23 de junho de 1629. Cf. Anais do Museu Paulista (1922, p. 201), também disponível em AGI, CHARCAS 30 R.1, N.2, imagem 17.

28. No documento de nomeação de Céspedes Xeria para o cargo de governador do Paraguai, o próprio rei D. Felipe IV ordena que sejam enviados relatórios em dos bias (cf. CHARCAS 30 R.1, N.1, imagem 18). Céspedes é muito cuidadoso: por outra passagem sabe-se que para enviar esses documentos, a $1^{\circ}$ de dezembro de 1628 , despachou três soldados, seu criado e mais cerca de dez índios, os quais levaram os pliegos em um cofre forrado com encerado, acrescentando que "iam bem despachados e assegurados" (cf. AGI, CHARCAS 30 R.1, N.1, imagens 118 e 119). papel dos paulistas na formação do território nacional, tendo como personagem principal os bandeirantes, colocando-os lado a lado com Alexandre de Gusmão e - Barão do Rio Branco; com o patriarca e o imperador. Entretanto, até onde foi possível investigar, não há indícios ou evidências de que Taunay tenha ordenado fazer quaisquer alterações nas cartas que mandara copiar nos acervos nacionais e estrangeiros. No caso específico do mapa de Céspedes Xeria tal operação seria ainda mais improvável, uma vez que o desenhista responsável pela cópia encomendada por Taunay trabalhava a serviço do Archivo General de Indias e não tinha vínculos com o diretor do Museu Paulista. Passemos pois à apresentação dos originais e da cópia, para depois compará-los.

\section{OS DUPLICADOS DESSE MAPA}

Foi justamente na primeira edição dos Anais do Museu Paulista que Taunay fez publicar, entre outros documentos, duas cartas de Céspedes Xeria a sua majestade D. Felipe IV de Espanha. ${ }^{26}$ A primeira delas, escrita na Ciudad Real de Guayrá em 8 de novembro de 1628, informa que "ay enbio a vuestra magestad todo aquel Rio que andube ... en un boron que vine haciendo con tintas de yeruas. Vuestra magestad lo vea y luego ... oyga lo que le voy diciendo". O título dado à carta pelo Archivo General de Indias, por sua vez indica: "acompaña un mapa donde se indica su derrota". É o mapa que estudamos. Já a segunda correspondência, escrita em Assunção em 29 de maio de 1629, ao referir-se à carta anterior traz a interessante informação de que "... De la civd Real del guayra ... escrevi a UM [Vuestra Magestad] por sinco duplicados, dos por la via de lima y tres por la del Brasil". Em outra passagem, referindo-se a esses mesmos documentos, Céspedes, talvez equivocado, indica que mandou "despachar seis pliegos por duplicado para su magestad". ${ }^{27}$

Esse envio de mais de uma cópia era uma prática comum e até obrigatória na época, ${ }^{28}$ em função da precariedade das comunicações e risco de se perderem no caminho, em viagens acidentadas através de rios, montanhas escorregadias, fortes chuvas e outras dificuldades. Saint Hilaire e Von Martius, por exemplo, enviavam os exemplares de suas coleções botânicas por mais de uma via, em geral três: Belém do Pará, Rio de Janeiro e uma pessoalmente. Era a esperança de que pelo menos uma chegaria a seu destino. Céspedes, mais precavido, como se viu, enviou cinco ou seis exemplares, da carta e do mapa, ainda que na prática só houvesse dois conjuntos de documentos. Perdido um deles, perdiam-se todas as cópias que seguiam no mesmo malote. 
No Archivo General de Indias encontram-se dois conjuntos (carta e mapa), talvez os que foram despachados pela via de Lima. ${ }^{29}$ Atualmente estão localizados na mesma estante, caixa e dossiê que as cartas mencionadas. Em meio digital receberam nova coła ou código de referência, que diferem somente pelo acréscimo da expressão "BIS". ${ }^{30}$ Daqui em diante utilizaremos as expressões 17 e 17 bis (ou simplesmente bis), para referir-nos aos mapas, e as expressões $\mathrm{N} 1$ e $\mathrm{N} 1$ bis para as cartas.

Teria Taunay conhecimento dessa duplicidade? Quem ler com atenção verá que a cota do Archivo General de Indias, transcrita no primeiro tomo da já mencionada obra de Pablo Pastells, ${ }^{31}$ inclui ao final a expressão duplicado. Admitindo-se que Taunay conhecia a existência de mais de uma cópia, é de se perguntar se ele teria condições de especificar a Santiago Montero Díaz, o copista do arquivo sevilhano, qual dos dois exemplares ele deveria utilizar para executar o serviço. Acreditamos que, por não ter visto os exemplares, Taunay não teria consciência das diferenças entre ambas. Além disso, é importante que se tenha em conta que as expressões duplicado e bis indicam uma identidade substancial entre as duas versões. Pelas discussões com Belmonte, das quais trataremos mais adiante, fica claro que ambos desconheciam o mapa 17. As Figuras 1 e 2 mostram esses duplicados, que serão comentados mais adiante, apontando as diferenças. Mas antes disso é importante caracterizar melhor essas e outras fontes utilizadas nesta pesquisa.

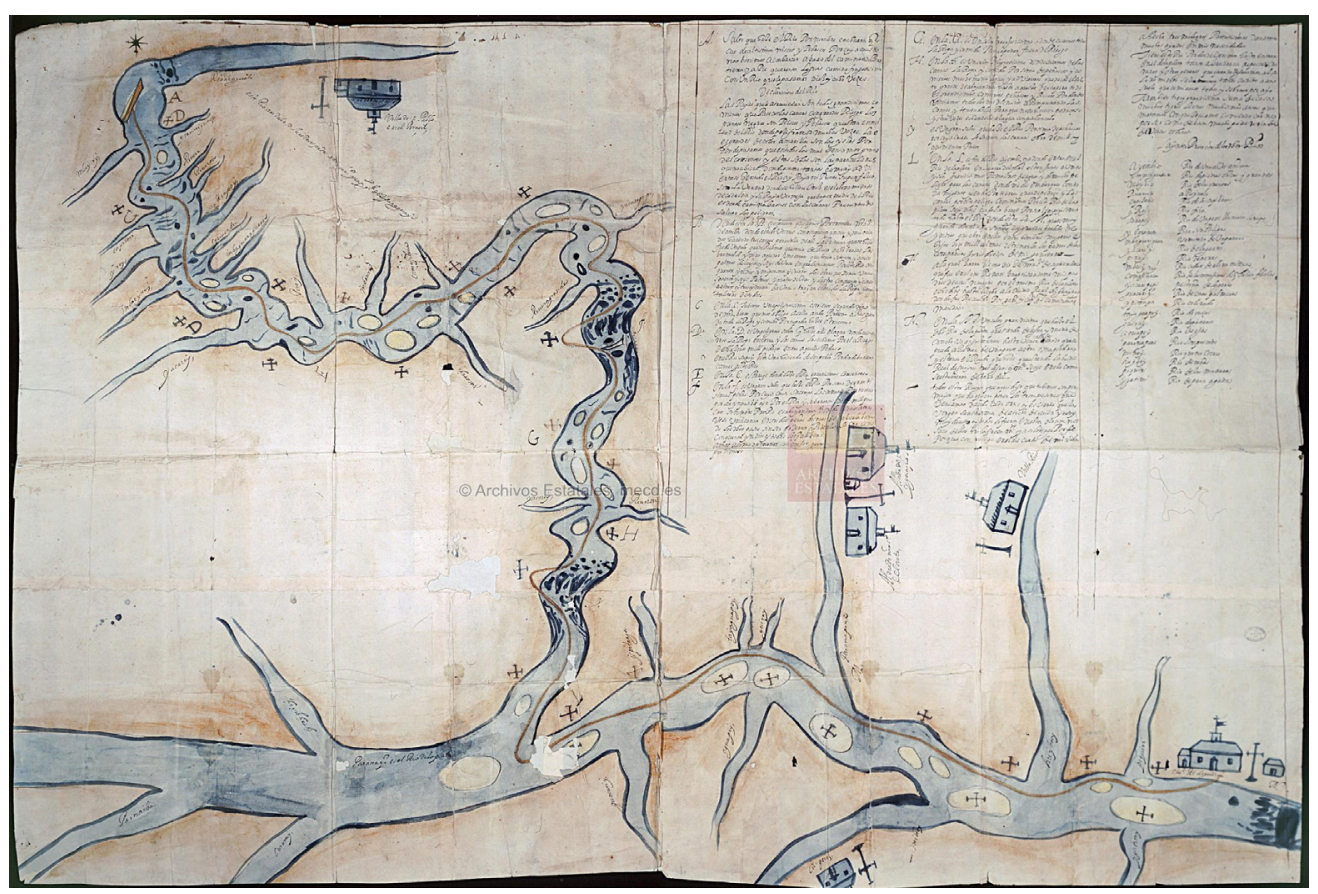

Figura 1 - Mapa 17 de Céspedes Xeria, original no Archivo General de Indias sob a cota ES.41091. AGI/27.3//MP-BUENOS_AIRES, 17, $78 \times 116 \mathrm{~cm}$, Sevilha. Fonte: Cépedes Xeria (1628a).
29. Pode-se supor que perdido o conjunto via Lima, perder-se-iam duas cópias, e perdido o conjunto via São Paulo, perder-se-iam três cópias. Como nos chegaram duas cópias, é menos provável supor que uma veio por Lima e outra por São Paulo; ou mesmo que se perdeu o conjunto de Lima e salvaram-se duas das três que foram enviadas por São Paulo.

30. Código ES.41091. AGI/27.3//MP-BUENOS_ AIRES,17 e 17BIS.

31. Cf. Pastells (1912, p. 422-423). 
32. Já havíamos estudado essa série cartográfica em projetos de iniciação científica com bolsa da Fapesp, números 06/555234 e 07/50.298-5.

33. Cf. Museu Paulista (1922).

34. A existência de um duplicado, como apontado, se encontra na obra de Pastells (1912). Bachiller Cabria (2008) também registra a existência das duas versões, assim como Cavenaghi (2011), ao incluir a expressão "BIS" na referência cartográfica, ainda que não use essa versão do mapa. A questão não é a prioridade, mas considerar nas pesquisas as duas versões do mapa.

35. Anais do Museu Paulista (1922).

36. Cf. Cortesão (1951, 1952), que são edições comentadas dos Manuscritos da Coleção de Angelis, da Biblioteca Nacional, Rio de Janeiro.

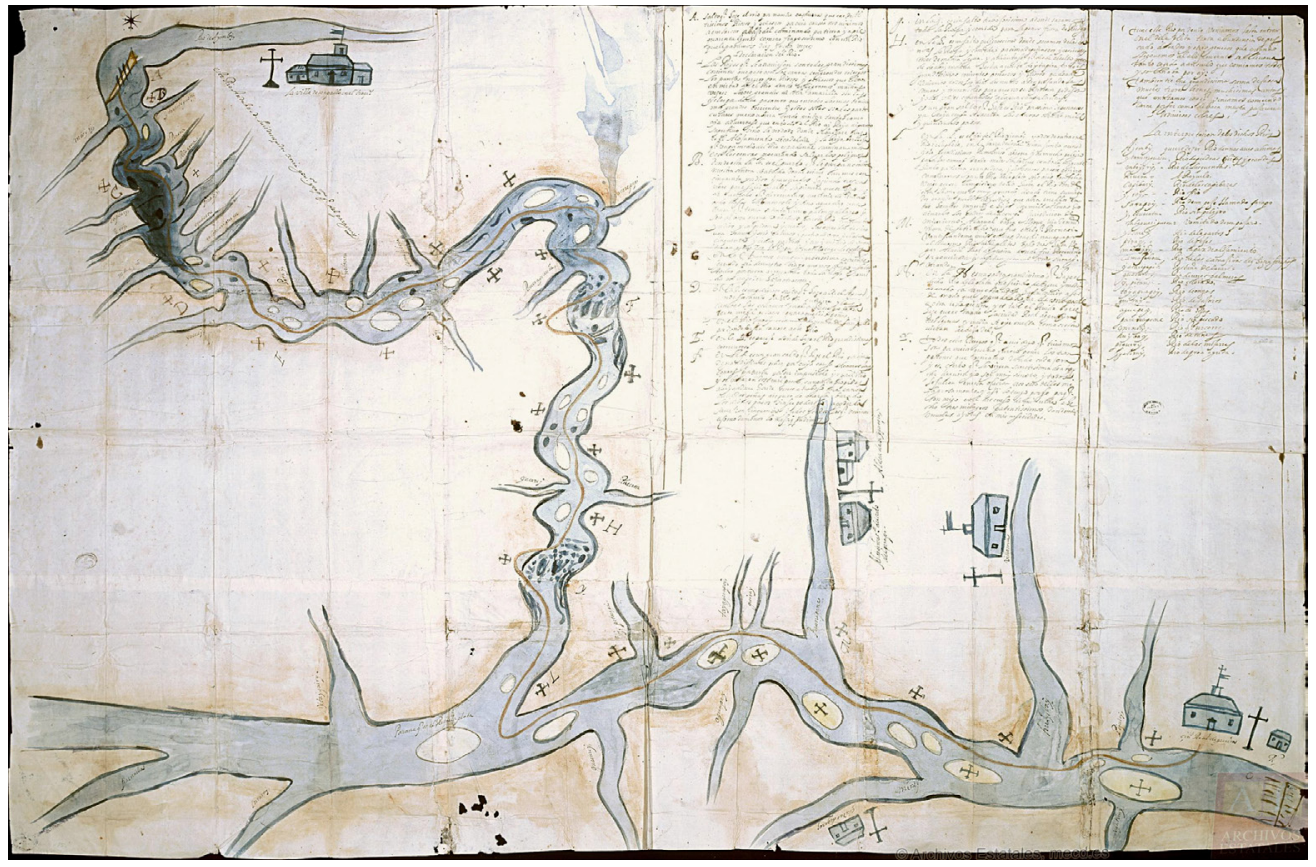

Figura 2 - Mapa 17 bis de Céspedes Xeria, original no Archivo General de Indias sob a cota ES.41091. AGI/27.3//MP-BUENOS_AIRES, 17BIS, 77,5 × 117cm, Sevilha. Fonte: Céspedes Xeria (1628b).

\section{AS FONTES UTILIZADAS}

Este trabalho se inspirou na necessidade de estudar mais profundamente ${ }^{32}$ os mapas fac-similares publicados por Taunay na Coletânea de mapas de 1922. ${ }^{33}$ Para isso recorremos ao Archivo General de Indias, obtendo as duas versões desse mapa, que comparamos com a cópia dessa Coletânea e constatamos que ela havia sido baseada no mapa 17 bis, ${ }^{34}$ e não no mapa 17. A seguir, estudamos os documentos textuais associados aos mapas publicados por Taunay ${ }^{35}$ e procuramos suas fontes originais, que não estão indicadas nessa publicação. Constatamos que a maioria desses documentos está no Archivo General de Indias, exceto dois deles, que atualmente encontram-se nos Manuscritos da Coleção De Angelis, da Biblioteca Nacional, editada com ampla introdução, notas e glossário por Jaime Cortesão. ${ }^{36}$

Constatamos também que o Archivo General de Indias possuía outros documentos elucidativos para esta questão que não foram publicados, e assim fizemos a transcrição paleográfica das páginas de interesse para este estudo. 
Mapas e textos são complementares e dialogam entre si, permitindo certas inferências. ${ }^{37}$ Da mesma forma, a existência de duas cópias de cada documento também enriqueceu o estudo, permitindo ampliar as análises.

Para evitar duplicações, nosso estudo começou focalizando o mapa 17bis que, como dissemos, serviu de base para a cópia encomendada por Taunay. Paralelamente, foram analisadas as variantes tanto do mapa 17 como das diversas cópias. A primeira delas, feita no Archivo General de Indias, é colorida, encontra-se atualmente no acervo cartográfico do Museu Paulista ${ }^{38}$ e está reproduzida na Figura 3.

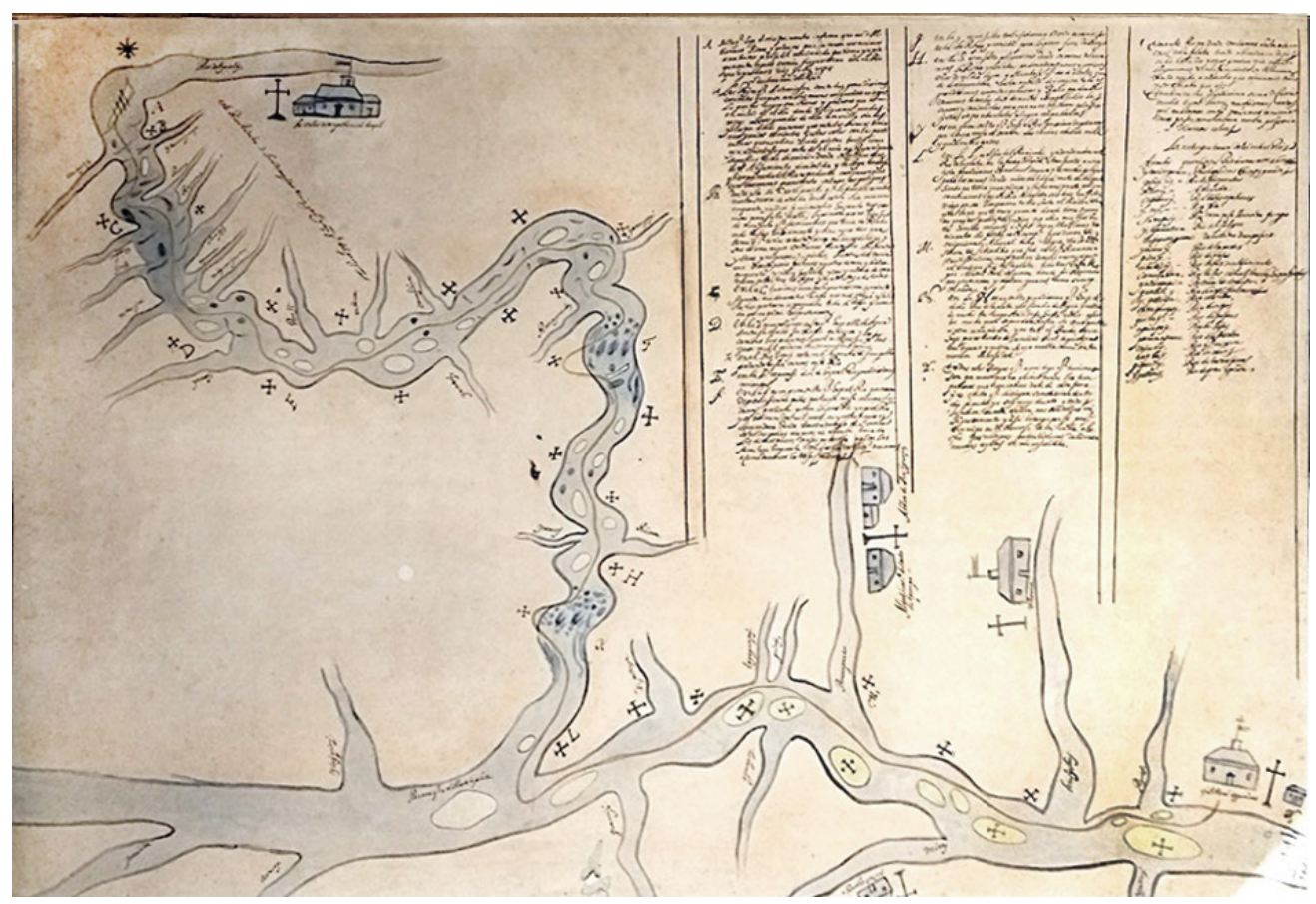

Figura 3 - Mapa de Céspedes Xeria, cópia de Santiago Montero Díaz a 29 de setembro de 1917 elaborada a partir do original 17bis. Localizável no Museu Paulista mediante a cota colocada no verso IC 10239, 78,9 × 117,6cm, São Paulo. Fonte: Céspedes Xeria (1628c).

A partir dessa versão, foi impressa uma cópia em preto e branco, em tamanho real, para a Collectanea de mappas ${ }^{39}$ comemorativa do Centenário, e em escala menor para as duas edições da mencionada Na era das bandeiras. Em seu capítulo A viagem de D. Luis de Céspedes Xeria, Taunay analisa esse mapa tomando como fontes as duas cartas enviadas por Céspedes Xeria ao rei em diferentes ocasiões; o relato da viagem escrito pelo governador, publicado nos Anais do Museu Paulista; ${ }^{40}$ uma relação feita por Céspedes, presente no Archivo General de Indias, que Taunay menciona sem citar a fonte ${ }^{41}$ e, é claro, a cópia
37. Monbeig (1957, p. 45) e Cintra (2015b).

38. Esse mapa foi reencontrado no Museu Paulista durante as pesquisas deste trabalho.

39. Cf. Museu Paulista (1922).

40. Anais do Museu Paulista (1922, p. 191-212). Relato escrito em Assunção, a 23 de junho de 1629.

41. Cf. AGI, CHARCAS 30 R.1, N.1, imagens 27-160, em especial, imagens 34-37 e 118-119. 
42. Na reforma de 1815 a Real Academia Espanhola suprimiu o $\mathrm{x}$ do alfabeto, substituindo-o por $\mathrm{j}$, e por isso, o Archivo General de Indias e todos os demais arquivos grafam atualmente Céspedes Jeria (o som do $\mathrm{x}$ nessa língua assimilava-se ao j). Mantivemos a grafia tal como esse autor se assinava no século XVII. Tenha-se em conta também que, no século XVII, havia costumes, mas não uma regra gramatical que ditasse como devem ser escritas as palavras, e assim, havia liberdade de grafar de uma ou outra maneira.

43. Acrescente-se somente que, por seus escritos, sabese que antes de casar-se com D. Vitória era viúvo e deixara dois filhos na Espanha. Com efeito, na segunda carta ao rei, de 29 de maio de 1629 , quase ao final, pede que "me haga merced de su real cédula de encomenda para uno de dos bijos que tengo" (Anais do Museu Paulista, 1922, p. 232).

44. Cf. Harley (2005, p. 6368).

45. Cf. Cintra (2015a).

46. Cf. Cintra e Oliveira (2014).

47. Cf. Cintra e Furtado (2011). da versão 17 bis, com sua rica legenda. No apêndice documental A2 transcrevemos essa legenda.

Nesse ponto é interessante focalizar o autor do mapa e suas cartas ao rei que complementam o documento cartográfico.

\section{AUTORIA E DATA}

Vida e ventura de Luis de Céspedes Xeria ${ }^{42}$ estão descritas por Taunay na bibliografia citada (particularmente $\mathrm{Na}$ era das bandeiras). ${ }^{43} \mathrm{Em}$ todo caso, levantase a questão da autoria do mapa em um sentido mais profundo, considerando também as discussões de John Brian Harley. ${ }^{44}$

Na produção de um mapa manuscrito podemos distinguir três momentos ou fases, ações e autores, que podem coincidir ou não. A primeira é o levantamento de dados, seguida da elaboração ou desenho do mapa e, por fim, a confecção de uma possivel cópia.

Por exemplo, Diogo de Campos Moreno levanta, na segunda metade do século XVI, os dados da costa do Brasil e Luis Teixeira elabora um texto e desenha os mapas do Roteiro de Todos os Sinais; ${ }^{45}$ o padre Cristóvão de Acunha levanta latitudes e distâncias no Rio Amazonas e tanto Sanson como o conde de Pagan (meados do século XVII) desenham mapas; ${ }^{46}$ Bourguignon Danville (meados do século XVIIII, cartógrafo de gabinete, elabora seus mapas a partir de muitas fontes; Guillaume Delisle (no início do século XVIII) reforma a cartografia mundial a partir de mapas anteriores e de longitudes observadas por muitos outros. ${ }^{47}$ Em todos esses casos, o mapa foi atribuído ao autor do desenho, em parte pelo grande trabalho que tiveram. Em alguns deles são citadas, no próprio mapa ou documento anexo, as fontes em que se baseiam. Os copistas, na maioria dos casos, não são citados, por sua tarefa ser considerada de menor relevância (cópia); ainda que em alguns casos se indique copiado por, mormente quando são incluídas alterações ou atualizações.

Hoje existe maior consciência da necessidade de reconhecer o trabalho de cada ator do processo, o que é facilitado quando se criam os chamados metadados de um mapa. No caso concreto, Céspedes indica que ele mesmo veio colhendo os dados (borrón que bine haciendo, Apêndice A 1, linhas 71-72) e que desenhou o mapa para anexar à primeira carta que enviaria a Felipe IV. Além disso, os longos dizeres inseridos como legenda do mapa estão em primeira pessoa (estive, 
andei, eu e meus criados e outras expressões semelhantes). Depois, Céspedes Xeria contou com a ajuda de um ou mais amanuenses para fazer as diversas cópias: isso se deduz pelo fato de as legendas dos dois mapas apresentarem caligrafias diferentes. Por sua vez, as duas cópias das cartas solidárias aos mapas apresentam a mesma caligrafia (e iguais à legenda de um dos mapas), mas não são autógrafas, o que se deduz pelo fato de estarem assinadas como Don Luis de Céspedes Xeria. Pela tradição epistolar da época, nenhum nobre se dirigia ao rei nomeando-se Don, ${ }^{48}$ fato que nos permite inferir que as cartas foram escritas por um amanuense. Outras razões são o tipo de letra e a análise linguística. ${ }^{49}$

Por outro lado, a legenda dos mapas e as cartas parecem escritas ao ditado, fato perceptível pela grafia de certas palavras que possuem sons idênticos: b e v; x e j. Por exemplo, na legenda do mapa 17bis, muitas vezes o som da letra $\checkmark$ é grafado por b: benimos, aberla, ba, bacas, obejas etc., em contraposição a venimos, averla, va, vacas e ovejas que aparecem na legenda do mapa 17. Da mesma forma se processam as mudanças abajo por abaxo, alojamiento por aloxamiento, entre outras trocas.

Frago-Gracia, ${ }^{50}$ analisando o texto da carta N 1 (correspondente ao mapa 17), elogia sua correção e deduz que o texto, embora não seja um autógrafo, foi escrupulosamente revisado pelo autor, que denota ser culto e respeita a tradição linguística, mostrando certo andaluzismo fonético, ${ }^{51}$ com o que é provável que fosse dessa região da Espanha. Por sua importância, transcrevemos a versão 2 da carta (correspondente ao mapa bis) no Apêndice documental A 1 .

$\bigcirc$ mapa foi datado pelo Archivo General de Indias como sendo de 8 de novembro de 1628, o que é razoável, pois é um anexo de uma carta com essa data. Pequena margem de variação seria admissível, já que é praticamente impossível elaborar cinco ou seis cópias da carta e do mapa no mesmo dia. Ainda hoje colocamos datas aproximadas ou simbólicas para a edição de um livro ("acabou de imprimir-se em..."), assim não nos parece descabida a solução de indicar uma mesma data para a carta e o mapa em todas as vias.

Pode-se ainda questionar o papel dos amanuenses na elaboração desses mapas; ou seja, em que medida eles poderiam ter introduzido variantes nas diversas cópias. Era prática corriqueira e indispensável que um governador da época tivesse entre seus criados pelo menos um amanuense encarregado de conservar os papéis e tintas e redigir documentos, além de, no caso, desenhar mapas. Mas a carta mostra, por seu conteúdo e estilo, que se trata de uma pessoa culta e com um tratamento a sua majestade que não é própria de um amanuense. Assim, chega-se à conclusão de que as cartas e os mapas foram escritos e desenhados ao ditado e sob a supervisão direta de Céspedes. ${ }^{52}$ Parece-nos que, nesses pressupostos, os amanuenses não
48. Don, de Dominus (senhor), indica tratar-se de um fidalgo, título conferido pelo rei.

49. Para estas questões, mantivemos intensa correspondência com Juan Antonio Frago-Gracia, filólogo espanhol e catedrático emérito de história da língua espanhola da Universidade de Saragoça. Cf. Frago-Gracia (2005).

50. Frago-Gracia (2005).

51. Frago-Garcia (2005, p. 11-37). $\mathrm{O}$ autor transcreve a versão N1 desta carta.

52. Cf. Frago-Garcia (2005). 
53. O Dicionário da Real Academía Española indica para borrón: denominação que por modéstia costumam dar os autores a seus escritos; primeiro traçado e não definitivo; esboço, ideia preliminar. introduziram variantes substanciais ao que esse governador do Paraguai pretendia com o material, e se há alguma, foi feita com o consentimento dele.

Aprofundemos, pois, no estudo desse mapa e nos objetivos de seu autor.

\section{DESCRIÇÃO GERAL DO MAPA E SUA FINALIDADE}

Primeiramente, deve-se levar em conta que a finalidade declarada do mapa era acompanhar a carta enviada ao rei, buscando facilitar seu entendimento; ilustrar o trajeto de São Paulo até Guayrá, pelos rios Tietê e Paraná. Além disso, Céspedes, como todo governador, tinha a obrigação de escrever prestando contas de seus atos ao rei e, demais, ele queria pedir expressamente que os cinco anos de seu mandato começassem a correr a partir da data de sua chegada ao Paraguai, pois demorou quase dois anos nessa viagem, em razão das diversas dificuldades encontradas desde Sevilha até Assunção. Por fim, também está presente o desejo de agradar e mostrar seus bons serviços e préstimos ao rei $D$. Felipe IV: boas cartas e bonitos mapas (o poder das imagens) causam boa impressão e favorecem as petições gerais e solicitações de mercês, como fez para um de seus filhos do primeiro casamento.

Mais do que um mapa de uma ou mais regiões, trata-se da descrição cartográfica de um trajeto, representado em linha vermelha para maior destaque, incluindo o posicionamento de cidades, vilas e aldeamentos indígenas.

Quanto a sua natureza, em sua humildade de ocasião, Céspedes classifica-o como um borrão, um rascunho, ${ }^{53}$ ainda que não deixe de causar boa impressão visual. Nesse tipo de mapa, não importam tanto as coordenadas, o sistema de projeção, a escala, a precisão geométrica, o tamanho e a uniformidade absoluta dos símbolos; enfatiza-se a posição relativa, a topologia, o esquema.

As dimensões desse mapa (praticamente idêntica nos dois) são de 1,18 $\times$ $0,79 \mathrm{~m}$. Na versão bis, por exemplo, nota-se uma grande dobra vertical ao meio, em que o mapa esteve rasgado e cuja restauração não conseguiu recuperar totalmente. Há outras dobras nessa direção, perfazendo um total de doze. Na outra direção há quatro dobras com espaçamento aproximadamente igual e dois menores nas extremidades. Por essas marcas pode-se deduzir que o mapa em sua forma dobrada (para o transporte e anexação a uma carta) teria $10 \times 16 \mathrm{~cm}$, aproximadamente. Essa forma dobrada é característica dos pliegos a que Céspedes se refere em suas cartas. 
Por outro lado, todo mapa possui uma posição preferencial para o leitor, que advém, dentre outros motivos, dadireção em que a legenda e outras informações estão escritas. Assim, o mapa em questão está no formato que atualmente chamamos de paisagem, sendo que o rio Paraná corre paralelamente à maior dimensão, chamada horizontal por convenção. Toda a legenda está paralela a ela e a grande maioria dos textos é legível com o mapa nessa posição, frente ao leitor. As exceções são Xerez (ou Gerez ou Jerez) nos dois mapas e São Paulo no mapa 17, posição que foi modificada ou corrigida no mapa 17 bis. As edificações aparecem paralelas aos rios mais próximos e com a frente voltada para eles, salvo as de São Paulo no mapa 17 bis.

Com relação à distribuição de massas, a legenda ocupa o quadrante superior direito; o Tietê, os quadrantes da esquerda; o Paraná, os inferiores; e as aldeias e outras povoações, o quadrante inferior direito.

A legenda está dividida em três colunas, separada por margens duplas, desenhadas antes da escrita, começando na margem superior e terminando imprecisamente na região do desenho dos afluentes da margem esquerda do Paraná. Ela inclusive transmite a impressão de que o desenhista receava que o espaço não fosse suficiente para conter o texto e, por isso, avança na primeira coluna sobre o rio Paranapanema, sem entretanto se sobrepor à missão de Santo Inácio. Na cópia 17 bis há uma linha a menos nessa coluna, talvez por se perceber que o texto poderia ser deslocado para a próxima coluna e deixar espaço para desenhar o torreão e a haste no topo dos ícones.

Taunay denomina essa legenda por Dizeres que o acompanham. $\bigcirc$ próprio autor, depois de um parágrafo inicial, pula uma linha e centraliza na coluna o que seria o título, "Declaración del Rio", que talvez pudesse preceder qualquer outra explicação.

A legenda, como em muitos outros mapas, utiliza letras de $A$ a $Y$ para estabelecer uma ligação entre o acidente geográfico do mapa, identificando-o e situando sua explicação na legenda com o mesmo caractere. A letra $A$ indica uma cachoeira, junto com uma explicação geral. Após o título também há uma explicação geral, seguida das demais letras, de $B$ a $Y$, de montante a jusante, com uma interpolação tardia após a letra $D$ para explicar o rio Sarapuí, que ele havia saltado por desatenção. Após a letra Y há mais algumas explicações gerais e uma tabela com o título "La interpretación de los dichos Rios", em que explica o significado dos nomes tupis-guaranis dos diversos cursos d'água de seu mapa, com exceção dos três afluentes do Paraná a montante da foz do Tietê. 
A simbologia é, em grande parte, explicada nessa legenda: as cruzes, de quatro braços iguais e com travessas nas pontas, correspondem aos locais nas margens dos rios onde a expedição montou acampamentos; os riscos transversais à torrente líquida correspondem aos locais com grande correnteza; os pontos negros correspondem a pedras pontiagudas afloradas no meio do rio e a penhascos; os grandes "ós" amarelos (por semelhança com a letra do alfabeto) identificam as ilhas por onde passaram; a linha vermelha no meio do rio, e saindo dele nos dois grandes saltos, indica a rota seguida. Além dessas declaradas explicitamente, há duas canoas desenhadas ao longo do rio: a primeira no ponto de partida e outra no salto de Avanhandava, junto a duas pedras; a identificação desse símbolo se dá justamente porque o autor menciona explicitamente que uma delas ficou presa entre duas rochas após passar essa cachoeira. Há também o que consideramos uma rosa dos ventos simplificada no canto superior esquerdo; somos levados a isso pelo fato de, em geral, nesses ícones constarem as quatro direções principais e as quatro secundárias, a intervalos de $45^{\circ}$, com a flor-de-lis, apontando para o norte e uma ponta em cruz apontando para leste. Assim encontramos as rosas dos ventos em mapas quinhentistas como os de Cantino, Pedro Reinel, Diego Ribeiro, para citar alguns. Nesse mapa, a direção do norte não corresponde ao norte geográfico, e pela configuração geral se deduz também que Céspedes não se serviu de uma bússola para o traçado dos rios. Por outro lado, a posição dessa imagem chama a atenção para o ponto de partida, local por onde se deve começar a ler um roteiro de viagem.

Outras duas convenções, não explícitas e que serão analisadas mais adiante, são os desenhos de edificações e do cruzeiro junto a cada uma delas.

Com relação ao uso de cores, o desenhista utilizou o vermelho lque ficou esbatido com o tempol para destacar a rota seguida e a canoa no ponto de partida; o azul em aguadas para hachurar os rios e edificações; o amarelo ltambém apagado com $\circ$ tempo) para as ithas e uma aguada marrom-avermelhada para o entorno das margens fluviais, com tons mais escuros nas proximidades de São Paulo no mapa 17. Por sua vez, o mapa 17 bis carregou as tintas no azul do Tietê em região próxima ao ponto de partida e possui um borrão dessa cor junto à primeira coluna da legenda.

Nos dois mapas há pequenos rasgões que não comprometem a leitura, bem como a marca de carimbo Archivo General de Indias e a atual marca AE Archivos Estatales, com copyright nas cópias digitais.

Depois de analisar os elementos cartográficos, cumpre estudar os componentes textuais presentes na legenda, que esclarecem diversos elementos e ajudam a contar a história da viagem. 


\section{A LEGENDA OU DIZERES QUE O ACOMPANHAM OU DECLARAÇÃO DO RIO}

No Apêndice documental A2 apresentamos a transcrição dessa legenda, pela importância de seus dizeres, incluindo a chamada interpretação dos rios. Essa transcrição também se justifica pois, dispondo de duas versões dos mesmos dizeres, pudemos corrigir pequenas dúvidas e solucionar algumas interpretações equivocadas do copista em Sevilha, que também influíram na análise de Taunay.

Nessa tarefa seguimos literalmente a legenda do mapa 17bis, que foi o exemplar copiado a mando de Taunay, comparando-o com aquela transcrita pelo próprio Taunay e apresentada na segunda edição de Na era das bandeiras. ${ }^{54} \mathrm{~A}$ diferença entre as duas legendas é da mesma natureza que se verificou na comparação das cartas N1 e N 1 bis, isto é, trocas de v por b e j por x. Há também outras diferenças de abreviaturas, troca de $i$ por $y, R$ por $r r$ e outras pequenas variantes. Em ambas, o estilo é um tanto confuso, o que se agrava ainda mais pela falta de vírgulas e pontos. Acrescentamos essa pontuação e os acentos da ortografia atual para maior clareza, tal como fazem atualmente alguns linguistas.

Como resultado de nossa comparação destaca-se a fidelidade do copista ao original 17 bis na forma das letras e caligrafia de uma maneira geral. Ainda que em pontos pequenos, o mapa 17 difere muito mais do 17 bis do que a cópia de Taunay com este original.

Dando continuidade ao estudo de Céspedes, passamos à análise da cronologia de sua viagem, que foi elemento decisivo para interpretar algumas afirmações suas nas cartas e no mapa.

\section{CRONOLOGIA DA VIAGEM}

Neste item, como nos anteriores, procuramos não repetir o que já foi dito por Taunay, mas completar com algumas informações não mencionadas ou corrigir alguma pequena interpretação equivocada do texto. Em Taunay encontra-se a informação que ele se baseou na "Relación de viaje que temos à vista e vamos analisar". ${ }^{55}$ Esse texto difere da relação publicada no Anais ${ }^{56}$ e encontra-se no Archivo General de Indias, disponível em meio digital. ${ }^{57}$

Como se verá, Céspedes é impreciso nas duas datações ou formas de dizer, que chegaram a confundir Taunay. Assim, para estabelecer a cronologia, foi importante a correspondência enviada pelos missionários jesuítas ao governador
54. Taunay (1922b, p. 6061).

55. Taunay (1922b, p. 96).

56. Anais do Museu Paulista (1922).

57. AGI, CHARCAS 30 R.1, N.1, p. 27-160, principalmente p. 34-37. Taunay cita literalmente diversas passagens desse documento, colocando expressões entre aspas. 
do Paraguai, recolhidas na mesma edição dos Anais, pois estas indicam o dia do recebimento de cartas e a data e o local em que escreveram as suas. A Tabela 1 resume essa cronologia de forma sintética, sendo que indicamos em itálico as datas prováveis; as demais estão documentadas.

Tabela 1 - Efemérides de Céspedes, da saída da Espanha à chegada em Assunção.

\begin{tabular}{|c|c|}
\hline Data & Efeméride \\
\hline $06 / 02 / 1625$ & $\begin{array}{l}\text { Nomeação como governador do Paraguai. Era um fidalgo que havia servido no } \\
\text { Peru e no Chile, encontrando-se em Madri nesse momento. Vai para Lisboa, onde } \\
\text { permanece bastante tempo. }\end{array}$ \\
\hline $18 / 04 / 1626$ & $\begin{array}{l}\text { Embarca em Lisboa para a Bahia (quarenta dias de viagem). Demorou cerca de } \\
\text { vinte meses nessa cidade em função de variadas dificuldades. }\end{array}$ \\
\hline $11 / 01 / 1628$ & Parte de Salvador para o Rio de Janeiro (34 dias de viagem). \\
\hline $04 / 02 / 1628$ & $\begin{array}{l}\text { Chega ao Rio de Janeiro, onde faz amizade com os Correa de Sá e se casa com } \\
\text { D. Vitória de Sá (quatro meses e quatro dias de estadia). }\end{array}$ \\
\hline $08 / 06 / 1628$ & $\begin{array}{l}\text { Deixa o Rio de Janeiro em direção a Santos, com vinte dias de casado, segundo } \\
\text { ele. }\end{array}$ \\
\hline $18 / 06 / 1628$ & Chega a Santos, onde fica por onze dias, partindo para São Paulo. \\
\hline $30 / 06 / 1628$ & $\begin{array}{l}\text { Chega a São Paulo e se prepara para a viagem fluvial. Pode ter chegado a } 1^{\circ} \\
\text { ou } 2 \text { de julho. }\end{array}$ \\
\hline $16 / 07 / 1628$ & $\begin{array}{l}\text { Parte em direção ao Guayrá, via Tietê e Paraná. Gasta em torno de cinco dias } \\
\text { para chegar ao porto fluvial, que ele indica estar a quarenta léguas (parece um } \\
\text { exagero). Encontra-se nas proximidades da atual Porto Feliz. }\end{array}$ \\
\hline $06 / 08 / 1628$ & $\begin{array}{l}\text { Permanece cerca de um mês nesse porto. Também parece um exagero pelos } \\
\text { dados e datas mais seguras informados adiante. Deve ter iniciado a viagem } \\
\text { fluvial a } 6 \text { de agosto. }\end{array}$ \\
\hline $07 / 09 / 1628$ & Chega à foz do Tietê, depois de navegar 32 dias. \\
\hline $08 / 09 / 1628$ & $\begin{array}{l}\text { Chega à foz do Paranapanema e toma terra em seus domínios. A data é certa, } \\
\text { pois indica que foi na festa de Nossa Senhora de setembro, que é a Natividade, } \\
\text { no dia } 8 \text {, em que completava quarenta anos de nascimento e batismo. }\end{array}$ \\
\hline $11 / 09 / 1628$ & $\begin{array}{l}\text { Sobe o Paranapanema, encontra um comboio descendo e volta ao Paraná. Deve } \\
\text { ter gasto dois dias nessa operação, pois indica que navegou por oito dias no } \\
\text { Paraná. A conta seria: um dia da foz do Tietê à foz do Paranapanema e mais } \\
\text { sete desse ponto (na volta da incursão pelo Paranapanema) até Ciudad Real del } \\
\text { Guayrá. Não esteve nas aldeias desse rio (Loreto e S. Inácio, que menciona), } \\
\text { como a redação parece indicar e Taunay recolhe essa impressão que o texto } \\
\text { passa. }\end{array}$ \\
\hline $18 / 09 / 1628$ & $\begin{array}{l}\text { Chega a Ciudad Real del Guayrá, na foz do Pequiri, nas proximidades do salto } \\
\text { de Sete Quedas. Informa de sua chegada às autoridades de Porto de Maracajú, } \\
\text { Ciudad Xerez, Vila Rica do Espírito Santo e Assunção. Lá permanece por cerca } \\
\text { de vinte dias. }\end{array}$ \\
\hline $12 / 10 / 1628$ & Parte para Vila Rica, pelo Paraná e lvaí. \\
\hline
\end{tabular}




\begin{tabular}{|c|c|}
\hline $23 / 10 / 1628$ & $\begin{array}{l}\text { Chega a Vila Rica, onde fica até } 2 \text { de janeiro de 1629. Toma diversas providên- } \\
\text { cias: envia visitadores às Reduções jesuíticas do Pirapó, Piqueri e outras; orga- } \\
\text { niza o Porto de Maracajú; proíbe a venda de armas aos índios; manda reedificar } \\
\text { a igreja destruída; procede à eleição de Alcaldes e Regidores. } \\
\text { Nessa estadia, a } 8 \text { de novembro de } 1628 \text { escreve a primeira carta a sua majest- } \\
\text { ade, acompanhada do mapa já mencionado. }\end{array}$ \\
\hline $02 / 01 / 1629$ & Parte para as aldeias de Pirapó, em uma viagem demorada. \\
\hline $21 / 01 / 1629$ & $\begin{array}{l}\text { Chega às aldeias de N. S. de Loreto e S. Inácio, onde permaneceu por nove } \\
\text { dias. Em } 28 \text { está em S. Inácio. }\end{array}$ \\
\hline $30 / 01 / 1629$ & Sai das reduções em direção a Ciudad Real del Guayrá. \\
\hline $06 / 02 / 1629$ & $\begin{array}{l}\text { Escreve a relação dos acontecimentos de seu governo até a data, a qual será } \\
\text { copiada em Assunção a } 23 \text { de junho de } 1629 \text {. }\end{array}$ \\
\hline $16 / 03 / 1629$ & $\begin{array}{l}\text { No porto de Maracaju faz copiar e autenticar diversas cópias de cartas de jesuí- } \\
\text { tas. Daí parte para Assunção, pela via do porto de Terecañi. }\end{array}$ \\
\hline $10 / 05 / 1629$ & Chega a Assunção e toma posse oficial. \\
\hline $29 / 05 / 1629$ & $\begin{array}{l}\text { Escreve nessa data a segunda carta a sua majestade, não mais de vinte dias } \\
\text { após a sua chegada. }\end{array}$ \\
\hline
\end{tabular}

\author{
58. Apêndice documental \\ A1, linha 126. \\ 59. Apêndice A1, linhas \\ 129-130.
}

Um exemplo da imprecisão de Céspedes se nota nessa tabela, com relação ao mês que teria ficado no porto fluvial e que não pode ter sido tanto, confrontando com a data de partida de São Paulo, duração da viagem e data de chegada à foz do Paranapanema. Outra se refere aos dados de seu casamento, informados na carta a sua majestade. Por um lado, indica ${ }^{58}$ que aos oito dias de sua chegada casou-se com D. Vitória de Sá, o que é muito pouco tempo, e pouco abaix ${ }^{59}$ afirma que só esteve com sua mulher vinte dias antes de partir, dados que não se compatibilizam com sua estadia de mais de quatro meses no Rio de Janeiro.

Taunay descreve essa viagem fluvial seguindo de perto as informações do mapa e as descrições do próprio Céspedes, procurando deduzir os tempos gastos nos percursos através das cruzes colocadas ao longo do trajeto. Estas indicam realmente os locais de pouso, mas é enganoso pensar que entre uma e outra cruz foi gasto um único dia: há 19 pousos (no mapa 17bis) e o percurso foi vencido em 32 dias, o que dá uma média de quase dois dias entre um pouso e outro. Certamente se gastou mais tempo na transposição das grandes cachoeiras, com a varação das canoas, e também em algumas outras corredeiras. Além disso, as afirmações de Céspedes dão margem a dúvidas; por exemplo, a expressão "un Rio que le pasamos diez y ocho vezes", colocada antes de descrever o ponto de partida, levou Taunay a afirmar que o rio Tietê foi cruzado 18 vezes nesse curto trajeto feito a pé, algo que não faz sentido e parece-nos que se deve interpretar como ter cruzado esse rio ao longo de todo o percurso até a foz do Paranapanema. 
Com efeito, analisando as cruzes, vê-se que há 18 alternâncias de margem, na montagem dos acampamentos, durante o percurso.

Céspedes também induz a erro quando diz que navegou por oito dias pelo Paraná e que entrou pelo Paranapanema onde existem as reduções de Loreto e Santo Inácio. Isso induz a pensar que, nesse momento, o governador visitou as aldeias que constam no mapa - Taunay interpreta assim -, mas, de fato, ele só visitou essas aldeias mais tarde, depois de ter feito o mapa, como esclarecem seus relatos. Céspedes também não informa quanto tempo gastou para subir e descer - Paranapanema (talvez dois dias) e poderia parecer que esse tempo está incluído nos oito que gastou no Paraná e nesse afluente.

Depois de nos ocuparmos da cronologia da viagem e de ter anteriormente apontado as semelhanças entre os mapas, cabe agora olhar para as diferenças.

\section{AS DIFERENÇAS ENTRE OS DOIS MAPAS DUPLICADOS (17 E 17BIS)}

Da comparação, elemento a elemento, dos dois duplicados de 1628, surgem algumas diferenças. Em primeiro lugar, as cruzes que indicam locais de acampamento: no mapa 17 não estão desenhadas cinco cruzes que constam do mapa 17 bis, e por outro lado, esse mapa inclui uma cruz omitida neste últimos, na margem esquerda, junto à foz do Tietê. Isso fortalece a hipótese de que havia um original a partir do qual foram feitos esses dois duplicados: na operação de cópia não é difícil esquecer algo, sendo menos provável a inclusão de uma cruz em novo local.

Outras diferenças são: no mapa 17 o nome do rio Anhembi está colocado em sua margem, enquanto no 17 bis está sobre o rio; isso também ocorre com o Paranapanema e o Mineí. A alternância no sentido inverso ocorre com os rios Cururaí, Itaiguiri e Piqueri.

A canoa nas proximidades do ponto de partida contém quatro traços transversais (talvez indicando remos), no mapa $17 \mathrm{bis}$, que faltam no outro. A letra $B$ está desenhada como um $D$, por engano, no mapa 17, enquanto no segundo foi colocado um $D$, mas foi corrigido por cima para B. A letra $G$ está borrada no mapa 17 bis.

As inúmeras ilhas se correspondem nos dois mapas, mas no 17 bis uma delas foi transformada em pedra (ponto preto), assim como há uma transformação no sentido inverso, como se pode conferir no trecho entre as letras $D$ e $E$. $O$ 
tamanho dessas ilhas varia ligeiramente de um mapa para outro. Os saltos de Avanhandava, Itapura e Sete Quedas são representados com cores claras no mapa 17 bis, e com tintas (azul escuro) bem mais carregadas no outro. Por sua vez, o mapa 17bis possui um azul de fundo muito forte no hachurado do Tietê entre os pontos $B$ e $D$, o que não ocorre no outro. No salto de Itapura do 17bis, ao hachurar o rio, preencheu-se com o mesmo azul, por engano, o espaço de terra entre a margem do rio e o trajeto da canoa feito por terra (linha vermelha). O rio Itaiguiri no mapa 17 bis está quase perpendicular ao Paraná, enquanto no outro forma um ângulo agudo em direção à montante.

Com relação aos topônimos, há pequenas variações de posição: La Villa de San Pablo en el Brasil está escrito em duas linhas em um dos mapas, e em uma só no outro, o que também acontece com Santo Inácio; iá na outra aldeia, ao nome Nossa Senhora de Loreto acrescenta-se del Pirapó em um deles.

Os pequenos seis ícones de cada mapa representando povoações através de casas apresentam diferenças não só entre si, mas também em comparação par a par. Por exemplo: Santiago de Xerez em um deles é uma casa simples (porta e duas janelas), e no outro está cortado pela margem do mapa e possui um início de balcão ou pequena torre sobre o telhado; as duas aldeias lem que o autor não esteve antes de fazer o mapa) possuem torres e bandeirolas em um e não no outro. Ciudad Real del Guayrá possui um anexo do lado esquerdo em um dos mapas e no outro não, e o outro anexo perdeu as janelas que tinha em um dos mapas; Vila Rica do Espírito Santo possui um denteado no telhado e um adorno sobre a porta que não constam do outro; São Paulo ganha um anexo na cópia 17 bis e sua posição é invertida em $180^{\circ}$ para que os dizeres possam ser lidos na posição natural da escrita do mapa. Os cruzeiros junto aos ícones possuem um pedestal variável, maior ou menor, independentemente de mapa ou edificação. No total há mais de 30 mudanças nesse nível de detalhe.

Para não nos alongarmos mais, comparamos somente São Paulo nas duas representações, pela importância de sua análise nos debates iconológicos e historiográficos. As Figuras 4 e 5 mostram ambas para comparação. Acrescentamos também, na Figura 6, a representação de São Paulo na cópia solicitada por Taunay.

As diferenças da Figuras 4, tomando a 5 como padrão, são: figura girada de 180; cruzeiro do lado esquerdo do ícone, e não direito; tamanho maior de seu pedestal; casa acrescentada à esquerda; bandeirola dentro do rio e com vento soprando para a esquerda, e não para a direita; acabamento sobre a porta principal; foi suprimido um hachurado do telhado da casa principal; torre da bandeirola deslocada para a direita, e não centrada como no outro desenho; 
diferenças nos dizeres: artigo la acrescentado; San por extenso e não abreviado; Brasil em minúscula; e z em vez de ç.

Embora possam parecer grandes, cartográfica e iconograficamente, essas diferenças são pequenas, a ponto dos cartógrafos e técnicos do Archivo General de Indias terem qualificado este documento como um duplicado, ou seja, substancialmente idêntico ao outro. Do ponto de vista iconológico, as diferenças podem ser interpretadas de muitas maneiras, inclusive na forma de Céspedes repensar o que havia feito na primeira versão (mapa 17) e porque resolveu mudar algo na versão 17 bis (aumentar os anexos da casa). $\bigcirc$ que não convém é atribuir a Taunay, no século XX, mudanças de Céspedes, no século XVII.

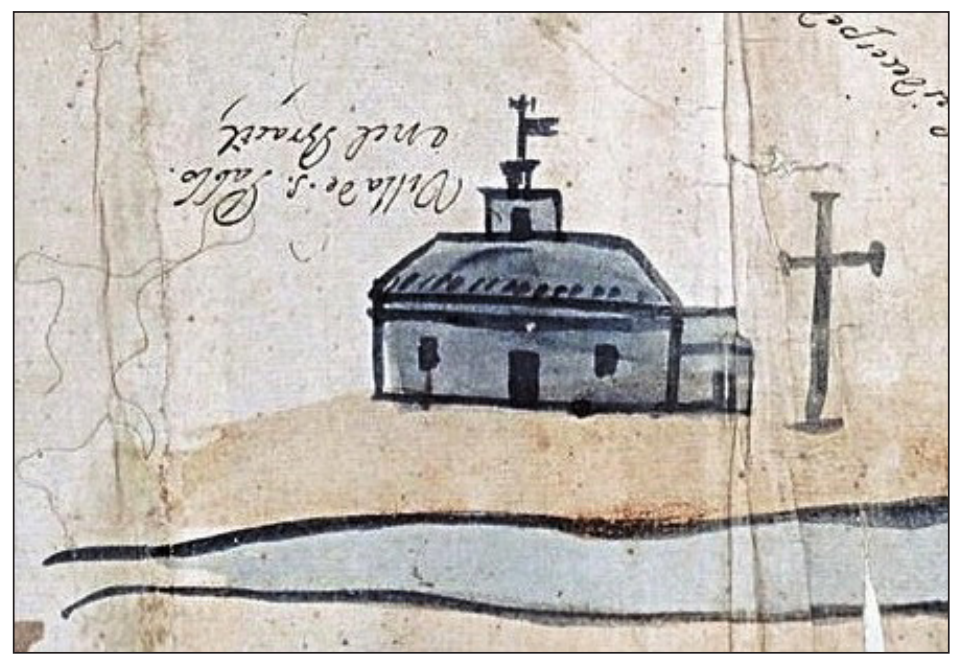

Figura 4 - Detalhe do ícone representando a vila de São Paulo no mapa 17, mantido no Archivo General de Indias. Fonte: Céspedes Xeria (1628a).

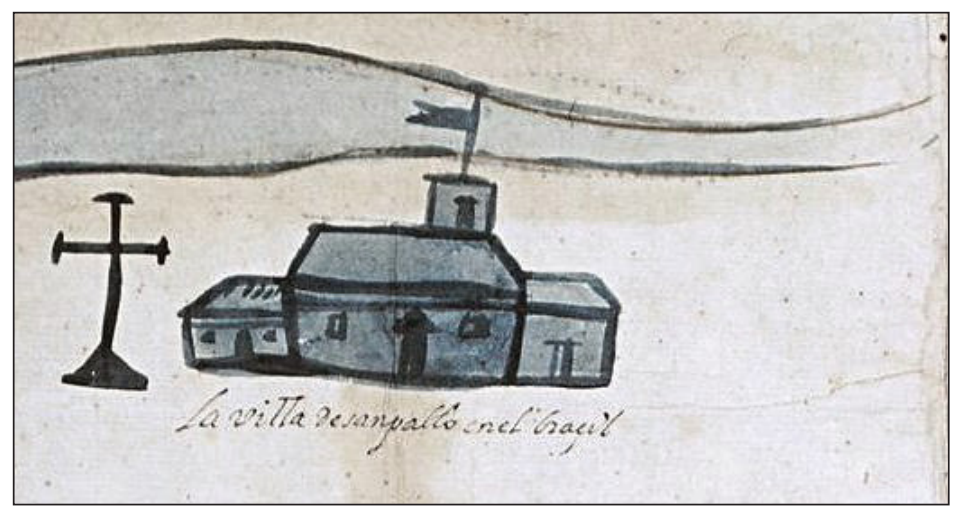

Figura 5 - Detalhe do ícone representando a vila de São Paulo no mapa 17 bis, mantido no Archivo General de Indias. Fonte: Céspedes Xeria (1628b). 


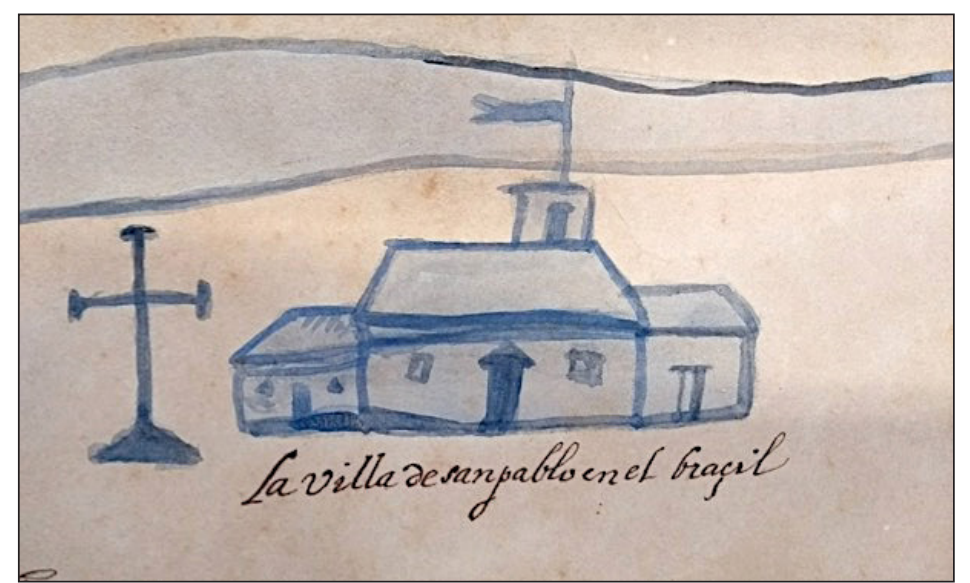

Figura 6 - Detalhe do ícone representando a vila de São Paulo na cópia feita por Santiago Montero Díaz à pedido de Taunay e mantida no Museu Paulista. Fonte: Céspedes Xeria (1628c).

\section{A HISTÓRIA DE UMA CÓPIA}

A mesma comparação entre os duplicados pode ser feita entre o mapa 17 bis e a cópia por Santiago Montero Díaz, seguindo a indicação precisa de Taunay: manter a maior fidelidade possível, incluindo as cores.

Fizemos uma comparação exaustiva entre as duas peças cartográficas e as diferenças são as seguintes: a letra $B$, corrigida sobre um errôneo $D$, foi grafada diretamente como B, sem primeiro escrever o D; o salto de Sete Quedas está interrompido em sua parte final. De resto, conferimos todas as ilhas (em amarelo), todos os pontos negros (pedras salientes no trajeto) e ondas transversais para indicar corredeiras. Só localizamos a falta de uma dessas ondas em uma das corredeiras. Os borrões e tons das cores foram mantidos, inclusive erros do original como uma hachura indevida fora do rio na região do salto de Itapura.

A letra é também uma imitação bem realizada da caligrafia do mapa 17 bis, a menos da maior firmeza e uniformidade do traçado, talvez em função da diversidade dos instrumentos de escrita de cada época.

Ana Cláudia Brefe - ao tratar da cópia do mapa de Céspedes Xeria em seu estudo sobre a construção da história nacional a partir da atuação de Affonso de Taunay à frente do Museu Paulista - destaca a grande preocupação do diretor em obter uma cópia fiel do mapa, solicitando inclusive que fosse em fac-símile, mantendo as mesmas dimensões e, se possível, as mesmas cores do original. Como já mencionado, Santiago Montero Díaz foi o correspondente de Taunay e responsável pela execução da cópia do mapa. Ao analisar a correspondência 
60. Taunay (1917 apud Brefe, 2005, p. 99).

61. Brefe (2005, p. 99-100).

62. Sobre isso e sobre a filiação de Taunay à escola metódica francesa, bem como a publicação de seu discurso inaugural na Revista do Instituto Histórico e Geográfico de São Paulo, cf. Anhezini (2003, p. 226-231). trocada entre ambos, a autora chama atenção para duas cartas, em especial as de 13 de agosto e de $1^{\circ}$ de outubro de 1917, nas quais Taunay destacava a importância de obter uma cópia "em fac-símile exato, sem redução das dimensões e divergência de cores". 60 Brefe ainda destaca que na correspondência trocada com outras instituições, o diretor do Museu Paulista perguntava pela possibilidade de se fazerem "cópias absolutamente fiéis aos originais", concluindo que isso indica como Taunay concebia o documento histórico, isto é, um "testemunho do passado e, nesse sentido, como matéria-prima indispensável para reconstruí-lo tal como ele aconteceu". 61

Como se sabe, Taunay filia-se à corrente historiográfica metódica, tendo como principais referências metodológicas os historiadores franceses Chales-Victor Langlois e Charles Seignobos. Karina Anhezini, em artigo com título significativo ("Um metódico à brasileira") destaca que, ao assumir a cadeira de história universal na Faculdade Livre de Filosofia e Letras de São Bento, Taunay fez um discurso inaugural no qual buscava resumir os "princípios gerais da moderna crítica histórica". Para tanto, tomou como base o livro seminal de Langlois e Seignobos intitulado Introdução aos estudos históricos, publicado originalmente em 1898. Segundo a autora, ao publicar seu discurso na Revista do Instituto Histórico e Geográfico de São Paulo em 1914, Taunay antecipou em três décadas a tradução do livro de Langlois e Seignobos para o português no Brasil, pois até então não contava com uma versão brasileira. ${ }^{62}$

No Brasil, uma de suas principais referências foi seu mestre e amigo Capistrano de Abreu, de quem era interlocutor assíduo. Dele herdou a profunda preocupação de realizar cópias fiéis dos documentos e mapas, como se constatou também neste caso. Outro ponto, em um segundo momento, são as leituras e usos que fez desses documentos, como nas exposições que montou, nos quadros de José Wasth Rodrigues, cuja execução orientou, e na interpretação dos símbolos presentes neste mapa, os quais analisamos a seguir.

\section{A CASA DA CÂMARA DE SÃO PAULO}

É bastante ilustrativa nesse sentido a elegante polêmica entre Taunay e Belmonte, nas páginas da Folha da Manhã nos meses de abril e maio de 1938. Esta se deu acerca dos ícones desse mapa, perguntando se o desenho correspondente à Vila de São Paulo representa ou pretende representar com fidelidade o aspecto de um edifício específico da cidade, mais precisamente a 
Casa da Câmara. ${ }^{63}$ Taunay respondeu afirmativamente a essa questão, e a partir daí incentivou e orientou José Wasth Rodrigues a pintar o que seria essa edificação, resultando em uma imagem que se difundiu e reproduziu à saciedade, como bem mostrou Cavenaghi. ${ }^{64}$ Essa hipótese de fidelidade ao aspecto do edifício supõe que Céspedes o tenha desenhado à vista, para não perder os detalhes com o passar do tempo e o esfumaçar-se da memória.

Cartograficamente falando, e sem concentrarmos em minúcias técnicas, os ícones de mapas podem ser basicamente de três tipos, em função da menor ou maior semelhança entre estes e a realidade representada. No primeiro, os ícones podem ser puramente convencionais, quando se utilizam símbolos que nada dizem respeito àquilo que representam, como um pequeno círculo para uma cidade, podendo-se utilizar símbolos semelhantes (menores ou de outra cor) para outros objetos de mesma natureza (uma vila, por exemplo). Não é esse o caso do mapa em questão.

No segundo tipo ocorre uma maior semelhança: escolhe-se um ícone com certa parecença: desenha-se uma edificação estilizada, casa ou igreja de tamanho pequeno para representar a povoação, podendo apresentar certas variações, das mais simples às mais complexas, para representar seus indivíduos, por exemplo: fazenda, capela, capela curada, freguesia, vila, cidade. Nesse caso, os símbolos são uniformes e existe uma legenda (cartela, explicação, notularium) que indica cada correspondência símbolo-realidade. Existiam mapas desse estilo em meados do século XVII, inclusive o de Joan Blaeu, ${ }^{65}$ em que as vilas e cidades em território português são representadas por edificações encimadas por uma cruz: S. Sebastián (Rio de Janeiro), Angra, S. Vicente e Santos (em posições invertidas), S. Pablo, Concepción (Itanhaém), Cananea. Já Parnaíba (Santana de) e Moxi (das Cruzes) aparecem com ícones simplificados. As reduções ou missões jesuíticas são representadas por uma cruz simples (um x com uma cruz): Loreto, S. Ignácio, S. loseph e todas as demais. Já Ciudad Real del Guayrá e Vila Rica do Espírito Santo, por uma cruz com duas travessas, indicando jurisdição episcopal para as aldeias indígenas dependentes do bispo no território desses dois núcleos coloniais. Naturalmente Blaeu acrescenta um notularium explicatio informando essas convenções. Aparentemente, não é este o caso do mapa de Céspedes, pois os desenhos são muito grandes ( 4 ou $5 \mathrm{~cm}$, contra os 3 ou $4 \mathrm{~mm}$ de um símbolo) e não são absolutamente iguais. Mas, como se sabe, Céspedes não é um cartógrafo profissional e desenha um borrón. É mais chamativo desenhar edificações que se destaquem no mapa e não se percam em função do reduzido tamanho. Mais que isso, deve-se ter sempre em mente o objetivo do documento e o público a que se destinava. Como já dissemos, trata-se de uma representação da viagem de
63. Imagens de edifícios como esse podem ser encontrados no mapa da cidade de 1841 , cópia da cartografia de Rufino Felizardo e Costa (1810), com ícones à volta que correspondem bem aos edifícios que pretende representar, sendo alguns baseados nos desenhos e aquarelas de Miguel Benício Dutra, Enders e Debret. E alguns até se podem comparar com as fotos de Militão.

64. Cavenaghi (2011).

65. Paraquaria vel Paraguay, cum adjacentibus, de 1665, disponível na biblioteca digital da Biblioteca Nacional (Rio de Janeiro), com a cota: cart 511917 . 
Céspedes Xeria que, junto com informações textuais, foi enviada ao rei para informá-lo do caminho que Céspedes realizara e das dificuldades encontradas até sua chegada ao Paraguai. Portanto, não era um mapa destinado a uma ampla circulação, exibição, ou mesmo um presente ao rei; trata-se praticamente de um anexo a uma carta, destinada a uma visualização bastante restrita, limitada aos assessores de Felipe IV, ao Conselho das Índias e, em última instância, ao próprio rei.

No terceiro tipo de ícone, os desenhos possuem uma semelhança maior com a realidade, escolhendo-se o edifício mais significativo para representar a povoação, sendo desenhado com a maior fidelidade possível conforme a habilidade do autor. Assim, o problema do intérprete é identificar o edifício escolhido, e se este é válido para todo o mapa, por exemplo, a Casa da Câmara ou a Matriz.

Para essa análise, dispomos hoje de um segundo mapa de Céspedes de 1628 que Taunay e Belmonte não conheciam, e que ajuda a lançar luzes sobre o problema. Assim, comecemos pelas similaridades e diferenças das doze imagens (duas cidades, duas vilas e duas aldeias em cada mapa), para inclusive testar a hipótese de uma certa uniformidade dos ícones. Todas elas possuem cruzeiros junto às edificações, porém há um só cruzeiro para Loreto e S. Inácio, por formarem uma unidade no mapa e na visão do governador, ainda que distassem cerca de $30 \mathrm{~km}$. Todas as imagens possuem uma casa com uma porta e duas janelas, ainda que haja anexos a algumas. Todas apresentam um torreão de pequenas dimensões e forma quadrada sobre o telhado, com uma abertura (para um sino ou para uma janela?); sobre este há uma haste, com bandeirola ao meio e terminação em cruz. As exceções aparecem somente na versão 17 bis, copiada por Montero Díaz: não há torreão nas aldeias em função do texto escrito invadir o desenho e não deixar espaço para tanto, nem em Xerez, provavelmente por descuido. São Paulo talvez não tenha a cruz do mapa, mas se estivesse desenhada, seria confundida com o traço grosso da margem do rio Tietê.

Assim, com diferenças quase nulas, parece-nos que Céspedes tentou uniformizar em seu aspecto básico os símbolos, e ao mesmo tempo conferir alguma diversidade a São Paulo e Ciudad Real por anexos ou casas próximas. Como dissemos, o fato de os ícones serem grandes, deve-se mais a uma razão estética que cartográfica.

Parece-nos, ao mesmo tempo, que o governador não pretende indicar um edifício concreto, desenhado à vista, pelas seguintes razões: a primeira é o fato de São Paulo estar desenhado de maneira diversa nas duas cartas; assim, ambas 
não podem ser imagens copiadas fielmente de uma mesma realidade. E o mesmo se diga de Ciudad Real.

Em segundo lugar, Céspedes não esteve em Pirapó e Loreto, e muito provavelmente também em Xerez antes de desenhar o mapa, como se mostrou na cronologia (Tabela 1). Portanto, ele ilustrou por imaginação ou no máximo por ouvir dizer, o que vai contra a hipótese de tê-lo feito à vista do edifício. Só depois de ter o mapa pronto visitou Loreto e Pirapó, e escreveu "tienen las dichas dos reduciones con hermosísimas iglesias que no las he visto mejores en las yndias, que he corrido todas las del Peru y Chile". 66 Isso concorda com a descrição da igreja de Loreto feita por Nicolau Durán em sua carta ânua de 1628: "La iglesia, que estava llena de gente, y me holge notablemente de verla porque es grande i de tres naves, tan bien hecha i tan alegre, y estaba tan adornada de flores". ${ }^{67} \bigcirc$ tamanho é compreensível, dada a quantidade de índios que devia abrigar nas missas e demais atos de culto. $\bigcirc$ contraste desses textos com a representação no mapa de Céspedes é patente. A conclusão geral é que não havia a preocupação de que a imagem desenhada no mapa fosse semelhante à realidade, e, portanto, que fosse feita olhando para ela. Assim, parece-nos que as figuras mais se assemelham a ícones, com grande parecença entre si, do que aos diversos edifícios presentes nas localidades.

Dando um passo além, podemos testar a hipótese de que se trata da representação de um edifício genérico, semelhante em todos os locais. Que edifício seria esse? Céspedes pretendia representar uma Casa de Câmara, uma Matriz ou uma igreja dos jesuítas? Haveria um edifício comum em todos esses locais? Sabese que nas duas reduções não havia nem Matriz nem Casa da Câmara; que em Vila Rica não havia Igreja (estava destruída e Céspedes incentivou sua reconstrução); nem nessa Vila, nem em Ciudad Real ou Ciudad Xerez havia igrejas dos jesuítas. Então, não há um edifício comum em todos os locais que possa representar as povoações.

Mas poderia, por generalização, Céspedes ter escolhido um edifício qualquer e desenhá-lo em todos os locais? $\bigcirc$ que queria ele representar com esse símbolo?

Para representar a Casa da Câmara e evitar a ambiguidade, deveria ilustrar um pelourinho ${ }^{68}$ (excluindo o desenho nas reduções), e não a cruz que aparece em todas as povoações. A cruz remete aos missionários, e a primeira coisa que faziam os jesuítas era isso: "plantó una cruz en el puesto que le pareció más acomodado para la fundación del pueblo que pretendia" ou "escogimos de nuevo puesto más ayroso y plantamos en el una hermosa cruz", ou ainda "Hallamos un sitio muy a propósito ... y llevantamos una muy hermosa cruz de siete brazas de alto en medio
66. Anais do Museu Paulista (1922, p. 188). Taunay, que havia editado esse texto, não se lembrou dele na controvérsia com Belmonte e para citá-lo recorre a uma passagem de Basílio de Magalhães na sua obra Expansão Geográfica.

67. Carta ânua do padre Nicolau Durán dando conta das reduções do Guairá, de 12 de novembro de 1628 , Documento XXXVIII da Coleção De Angelis, volume I, p. 213-214.

68. Pelas atas da Câmara de São Paulo (23 de maio de 1610) infere-se que havia pelourinho em São Paulo "de tijolo cozido e barro, de doze pés em quadro, três degraus de palmo e meio cada um, vinte e dois palmos de altura, e quatro palmos de largura em cada face". Um pé equivale a $33 \mathrm{~cm}$ e um palmo a $22 \mathrm{~cm}$ (Fina, 1962). 
69. Carta ânua do padre Nicolau Durán (ver nota 50), falando em concreto da redução de Nossa Senhora da Natividade de Acaraí (Coleção De Angelis, v. 1, p. 204-205) e da fundação da missão de Encarnação, nas proximidades do Tibaji (Idem, p. 239).

70. Cf. Fina (1962), e os periódicos citados que trazem a polêmica entre Taunay e Belmonte, em que se mostra que este último tinha razão. de la plaza". ${ }^{99}$ Há até hoje uma cruz nos remanescentes das aldeias de Carapicuíba (do século XVI, reconstruída no século XVIII) e São Miguel Paulista (de 1622, reformada no final do XVIII). $\bigcirc$ desenho da pequena cruz no topo do mastro também remete para um edifício religioso.

Por outro lado, das atas da Câmara de São Paulo lem mais de uma passagem) se depreende que, nessa época, o edifício onde funcionava tinha balcão e alpendre, elementos que não aparecem nesse desenho. Estamos em uma situação de confronto: ou seja, as atas escritas contra um desenho, que como mostramos é apenas um ícone-símbolo, e não o retrato de uma realidade observada. ${ }^{70}$. Nessa polêmica Taunay insistiu teimosamente que, para São Paulo, tratava-se de uma representação fiel da Casa da Câmara e Cadeia; Belmonte, com argumentos fortes e não contestados satisfatoriamente, rejeitou sua hipótese.

\section{CONSIDERAÇÕES FINAIS}

Ao longo destas páginas, contando com documentos cartográficos e textuais da época, analisamos o mapa de Céspedes Xeria em suas duas versões e na cópia encomendada por Taunay na ocasião da montagem da primeira sala do Museu Paulista dedicada exclusivamente à história (Sala A-10). Composta basicamente a partir de documentos cartográficos, selecionados com o que pôde conseguir em poucos meses, Taunay organizou a sala buscando narrar como se dera a evolução geográfica do continente, destacando o protagonismo dos paulistas a partir dos bandeirantes. Estes, por sua vez, aparecem representados na sala pelo retrato de Domingos Jorge Velho, que Taunay já encontrou pronto quando assumiu a diretoria do Museu, e reaproveitou-o na composição do cenário expositivo do novo espaço. Nesse processo de organização da sala e construção da narrativa da evolução geográfica do continente, o mapa de D. Luiz de Céspedes Xeria, bem como toda a documentação escrita contendo a narrativa de sua viagem, teve grande importância para Taunay. Sempre que tinha oportunidade o diretor os destacava, chegando mesmo a publicá-los nos periódicos paulistanos, na Revista do Instituto Histórico e Geográfico Brasileiro e, por fim, os capítulos de sua obra Na era das bandeiras, publicada em 1922, representando um episódio do grande movimento de penetração no continente.

O recurso a esses documentos coetâneos, incluindo os duplicados, ajudou a aprofundar a análise e compreensão desse mapa, bem como do modo de trabalhar de Taunay especialmente com a documentação cartográfica. Nesse sentido, como na visão de um bom metódico, é preciso distinguir dois momentos: 
o heurístico, em que se procuram os documentos, se verificam suas autenticidades para, enfim, se efetuar cópias fidedignas, e o hermenêutico, em que estes documentos são interpretados. Nessa última etapa entram em jogo a formação do historiador, a concepção de história da época, além do projeto de Museu que, tanto ele como aqueles que o nomearam para diretor, tinham, sendo essas compatíveis com as expectativas dos intelectuais da época e do público em geral.

Como se viu, para inaugurar essa sala ainda no primeiro ano de seu mandato, Taunay realizou uma intensiva busca documental, principalmente de mapas, sendo que o de Céspedes Xeria pode ser considerado "a joia da coroa". Depois, com mais calma, foi delineando e construindo um projeto de memória paulista, servindo-se, dentre outros documentos, desse mapa e do ícone da Casa da Câmara e da Cadeia. E, uma vez montada a narrativa, torna-se muito difícil recuar e admitir teses contrárias, como aconteceu na polêmica com Belmonte sobre os ícones do mapa, em que a razão assistia esse último e Taunay teimava em sustentar seus pontos de vista com malabarismos pouco verossímeis.

Ao perceber que não haveria consenso com seu interlocutor, e também para encerrar a discussão, Taunay exclamou: "Assim nos resta um recurso único. Esperemos que a voz dos séculos se faça ouvir, partida de algum arquivo europeu. Mas tal se dará? Parece-me muito pouco provável.... Enfim...". Acreditamos que, de acordo com a pouco esperançosa profecia de Taunay, a voz dos séculos se fez ouvir: essa ajuda para aprofundar na questão veio com o duplicado desse mapa, adormecido no Archivo General de Indias, em Sevilha.

Parece-nos, sobretudo, que este caso é um bom exemplo de como um novo documento pode impactar o estudo de uma questão já debatida. Pensamos que esta segunda versão lançou luzes no estudo desse mapa, no debate sobre a representação da Casa da Câmara de São Paulo e sobretudo nas dúvidas ou sombras que pairavam sobre o então diretor do Museu Paulista, de ter modificado estruturalmente esse documento cartográfico. A longo prazo essa dúvida poderia se estender a toda a atividade de Affonso de Taunay como pesquisador; ao questionamento sobre a fidelidade das inúmeras réplicas encomendadas e a credibilidade das instituições envolvidas nos processos de cópia: o Archivo General de Indias e o Museu Paulista. 


\section{REFERÊNCIAS}

FONTES MANUSCRITAS

Archivo General de Indias

AUDIENCIA DE CHARCAS: CARTAS DE GOBERNADORES. 1 e 2. CHARCAS,30,R.1,N.1 (172 imágenes e 46 imágenes). Sevilla: AGI, [s. d.]. Disponível em: <http://pares.mcu.es>. Acesso em: 25 out. 2018.

CÉSPEDES XERIA, Luis de. Mapa del río Ayembí (actual Tieté) y del Paraná, con sus afluentes, que recorrió Luis de Céspedes Jería, gobernador del Paraguay, al entrar en su jurisdicción desde Brasil. 1628a. 1 mapa: ms: $78 \times 116 \mathrm{~cm}$. Archivo General de Indias, Sevilla. MP-BUENOS_ AIRES, 17. Sevilla: AGI, [s. d.]. Disponível em: <http://pares.mcu.es>. Acesso em: 25 out. 2018.

Mapa del río Ayembí (actual Tieté) y del Paraná, con sus afluentes, que recorrió Luis de Céspedes Jería, gobernador del Paraguay, al entrar en su jurisdicción desde Brasil. 1628b. 1 mapa: ms: $77,5 \times 117 \mathrm{~cm}$. Archivo General de Indias, Sevilla. MP-BUENOS_AIRES, $17 \mathrm{BIS}$. Sevilla: AGI, [s. d.]. Disponível em: <http://pares.mcu.es>. Acesso em: 25 out. 2018.

Arquivo Permanente do Museu Paulista/Fundo Museu Paulista

CÉSPEDES XERIA, Luis de. Mapa del río Ayembí (actual Tieté) y del Paraná, con sus afluentes, que recorrió Luis de Céspedes Jería, gobernador del Paraguay, al entrar en su jurisdicción desde Brasil. 1628c. 1 mapa: ms: 78,9 × 117,6cm. Arquivo Cartográfico do Museu Paulista. IC 10.239. Cópia terminada por Santiago Montero Díaz a 29 de setembro de 1917.

FUNDO MUSEU PAULISTA. Correspondência enviada e recebida, Santiago Montero Díaz, pasta 104.

Biblioteca Nacional do Rio de Janeiro

CORTESÃO, Jaime (Org.). Jesuítas e bandeirantes no Guairá: 1594-1640. Introdução, Notas e Glossário por Jaime Cortesão. Rio de Janeiro: Divisão de Obras Raras e Publicações da Biblioteca Nacional, 1951. v. 1. Disponível em: <https://bit.ly/2EOLfOp>. Acesso em: 25 out. 2018.

. Jesuítas e bandeirantes no Itatim: 1596-1760. Rio de Janeiro: Divisão de Obras Raras e Publicações da Biblioteca Nacional, 1952. v. 2. Disponível em: <https://bit.ly/2O9FfPs>. Acesso em: 25 out. 2018. 
FONTES IMPRESSAS

ANAIS DO MUSEU PAULISTA. Commemorativo do Primeiro Centenário da Independência Nacional. São Paulo: Museu Paulista, 1922. v. 1.

MUSEU PAULISTA. Collectanea de Mappas da Cartographia Paulista Antiga (Cartas de 1612 a 1837, acompanhadas de breves comentários por Affonso D'Escragnolle Taunay). São Paulo: Cia Melhoramentos de S. Paulo, 1922.

TAUNAY, Affonso d'Escagnolle. Museu Paulista. Correio Paulistano, São Paulo, 24 dez. 1917. n. 19.564 , p. 2.

A viagem de D. Luiz de Cespedes Xeria. Correio Paulistano, São Paulo, 23 abr. 1919a. n. 20.043, p. 1.

Viagem complicada. Correio Paulistano, São Paulo, 27 abr. 1919b. n. 20.047, p. 1. Impressões de viagem. Correio Paulistano, São Paulo, 14 maio 1919c. n. 20.063, p. 1. Pelo Anhembi e o Rio Grande. Correio Paulistano, 23 maio 1919d. n. 20.072, p. 1.

As figurinhas do mappa-roteiro de don Luiz de Cespedes Xeria. Folha da Manhã, São Paulo, 24 abr. 1938. p. 8.

LIVROS, ARTIGOS E TESES

ANHEZINI, Karina. Museu Paulista e trocas intelectuais na escrita da história de Afonso de Taunay. Anais do Museu Paulista, São Paulo, v. 10-11, n. 1, p. 37-60, 2003.

Um metódico à brasileira: a escrita da história de Afonso de Taunay. Revista de História, São Paulo, n. 160, p. 221-260, 2009.

ARCHIVAL notes of Santiago Montero Díaz from the Archivo General de Indias. The Americas, Cambridge, v. 40, n. 4, p. 93-102, 1985.

BACHILLER CABRIA, Juan Vicente. Cartografia manuscrita do Brasil nas coleções espanholas (1500-1822). Salamanca: Universidad de Salamanca, 2008. 
BREFE, Ana Claudia Fonseca. O Museu Paulista: Affonso de Taunay e a memória nacional. São Paulo: Editora Unesp, 2005.

BIASON, Mary Angela. A música de farda: análise iconográfica da publicação Uniformes do Exército Brasileiro, 1720-1822, desenhado e aquarelado por José Wasth Rodrigues. In: CONGRESSO BRASILEIRO DE ICONOGRAFIA MUSICAL, 3., 2015, Salvador. Anais... Salvador: UFBA, 2015. p. 55-78.

CAVENAGHI, Airton José. A construção da memória historiográfica paulista: dom Luiz de Céspedes Xeria e o mapa de sua expedição de 1628. Anais do Museu Paulista, São Paulo, v. 19, n. 1, p. 81-113, jun. 2011.

CINTRA, Jorge Pimentel. As capitanias hereditárias no mapa de Luís Teixeira. Anais do Museu Paulista, São Paulo, v. 23, n. 2, p. 11-42, 2015 a.

CINTRA, Jorge Pimentel. Técnicas de leitura de mapas históricos: uma proposta. Revista Brasileira de Cartografia, Rio de Janeiro,v. 67, n. 4, p. 773-786, 2015b.

CINTRA, Jorge Pimentel; FURTADO, Júnia Ferreira. A Carte de l'Amérique Méridionale de Bourguignon D'Anville: eixo perspectivo de uma cartografia amazônica comparada. Revista Brasileira de História, São Paulo, v. 31, n. 62, p. 273-316, 2011.

CINTRA, Jorge Pimentel; OLIVEIRA, Rafael Henrique. Nicolas Sanson and his Map: The course of the Amazon River. Acta Amazonica, Manaus, v. 44, n. 3, p. 353-365, 2014.

DIAZ-TRECHUELO, Lourdes. A la mitad del camino. Madrid: Rialp, 1997.

FINA, Wilson Maia. Paço Municipal de São Paulo: sua história nos quatro séculos de sua vida. São Paulo: Anhambi, 1962.

FRAGO-GRACIA, Juan Antonio. El español por la ruta de los bandeirantes. Boletín de Filología, Zaragoza, v. 50, p. 11-37, 2005.

GENi, Bnei Atarot, 2018, voz CRISTINA Teixeira Leite, viscondessa de Taunay. Disponível em: <https://www.geni.com/people/Cristina-Teixeira-Leite-viscondessa-deTaunay/6000000021792971096>. Acesso em: 25 out. 2018.

MADRE DE DEUS, Frei Gaspar. Memória para a história da Capitania de São Vicente. São Paulo: Edusp, 1953. 
HARLEY, John Brian. Textos y contextos en la interpretación de los primeros mapas. In: LAXTON, Paul (Comp.). La nueva naturaliza de los mapas: ensayos sobre la historia de la cartografía. Ciudad de México, DF: Fondo de Cultura Económica, 2005. p. 59-78.

MATOS, Odilon Nogueira. Affonso de Taunay: historiador de São Paulo e do Brasil: perfil biográfico e ensaio bibliográfico. São Paulo: Museu Paulista, 1977.

MONBEIG, Pierre. Novos estudos de geografia humana brasileira. São Paulo: Difel, 1957.

PASTELLS, Pablo. Historia de la Compañia de Jesus en la Provincia del Paraguay (Argentina, Paraguay, Uruguay, Peru, Bolivia y Brasil) según los documentos originales del Archivo General de Indias. Madrid: Librería General de Victoriano Suarez, 1912. v. 1.

REY, Marcelo. El copista: Gaspar García Viñas entre la Biblioteca Nacional y la Facultad de Filosofia y Letras. Buenos Aires: Teseo, 2013.

TAUNAY, Affonso d'Escragnolle. Crônica do tempo dos Felipes. Tours: Imprimerie E. Arrault et Cie, 1910.

Na era das bandeiras: estudos de história Colonial Paulista. Revista do Instituto Histórico e Geográfico Brasileiro, Rio de Janeiro, v. 87, p. 383-531, 1920.

Mappa de D. Luis de Cespedes Xeria (1628). In: MUSEU PAULISTA. Collectanea de mappas da cartographia paulista antiga: cartas de 1612 a 1837, acompanhadas de breves comentários por Affonso D'Escragnolle Taunay. São Paulo: Melhoramentos de S. Paulo, 1922a. p. 3 .

. Na era das bandeiras. 2. ed. São Paulo: Melhoramentos, $1922 \mathrm{~b}$.

Artigo apresentado em 15/09/2017. Aprovado em 05/10/2018.

\section{(cc) BY}

All the contents of this journal, except where otherwise noted, is licensed under a Creative Commons Attribution License 
71. Frago-Gracia (2005)

72. AGI, CHARCAS 30 R.1,

N.1, imagens 1-4.

73. AGI, CHARCAS 30 R.1,

N.1, imagens 5-8.

74. ES.41091.AGI/27.3// MP-BUENOS_AIRES,17BIS.

75. ES.41091.AGI/27.3// MP-BUENOS_AIRES, 17.

\section{APÊNDICES DOCUMENTAIS}

\section{Apresentação e agradecimentos}

Apresenta-se neste apêndice documental a transcrição de dois textos associados ao artigo citado em epígrafe, ou seja, uma carta de D. Luis de Céspedes Xeria, governador do Paraguai, escrita em 8 de novembro de 1628, ao rei da Espanha, Felipe IV e a Legenda de um mapa em que se desenha o trajeto percorrido pelos rios Tietê e Paraná. Existem duas versões (duplicados) de cada um deles no Archivo General de Indias. Escolhemos para traduzir as versões copiadas facsimilarmente por Santiago Montero Díaz, técnico desse arquivo, por encomenda de Taunay em 1917. Embora já publicados entre nós, sua leitura ficou prejudicada nessa primeira versão pela interpretação deficiente de diversas palavras e pela falta de pontuação e acentuação, entre outras questões. Além disso, fazemos uma exaustiva comparação desses documentos com seus respectivos duplicados.

Devemos muito ao professor Juan Antonio Frago-Gracia, que em seu artigo, ${ }^{71}$ transcreveu e comentou a carta em sua primeira versão ${ }^{72}$ e gentilmente conferiu nossa tradução da segunda versão ou duplicado ${ }^{73}$ (Apêndice A1), a que Taunay conheceu e citou. Nossa correspondência com esse autor foi muito proveitosa para validar nossas conclusões, sanar dúvidas e conhecer melhor as antigas grafias do espanhol, bem como o cotidiano dos governadores e seus amanuenses nessa época. Com a orientação desse pesquisador, fizemos também uma nova tradução da legenda do mapa 17bis 74 (Apêndice A2) e a comparamos com a do mapa 17.75

Também agradecemos ao professor Eduardo de Almeida Navarro, pesquisador do tupi antigo da Universidade de São Paulo, para a interpretação dos nomes de rios citados por Céspedes Xeria na legenda de seu mapa. 


\section{Notas técnicas da transcrição}

1. /25 significa quebra de linha e número da linha seguinte. A barra dupla // significa, além disso, mudança de coluna ou de página.

2. Para facilitar a leitura, inserimos pontuação, acentuação e uso de maiúsculas. Por simplicidade, deixamos de colocar o pingo sobre o y li griega do castelhano) e omitimos alguns poucos sinais, quando não modificavam o sentido da expressão.

3. (sic) indica trecho grafado tal qual aparece no documento, para confirmar que não há erro de transcrição.

4. Na terceira página, faixa lateral direita, o final das linhas não aparece, por defeito do original ou da cópia, mas considerando a redação da outra carta e o início das palavras, pode-se presumir com razoável certeza as letras que faltam. Em todo caso, foram colocadas entre colchetes. 
76. Transcrição da legenda do objeto cartográfico identificado como ES.41091.AGI/27.3//MPBUENOS_AIRES, 17BIS, guardado no Archivo Geral de Indias, que foi copiado pelo engenheiro Santiago Monteiro Dias a pedido de Affonso d'Escragnole Taunay em 1917. Também é interessante observar que na descrição documental, o arquivista informa que este mapa está relacionado à correspondência enviada por Céspedes Xeria, governador do Paraguai, datada de 8 de novembro de 1628. Manuscrito em AGI, CHARCAS 30 R.1, N.1, imagens 5-8.

\section{APÊNDICE A1}

\section{Transcrição da Carta de 8 de novembro de 1628 bis $^{76}$}

\section{Señor}

Del Estado del Bracil y sus ciudades, la Baýa de Todos los Santos /2 y el Río Genero, dí qüenta a V. Magestad por muchas vezes de mis $/{ }^{3}$ grandes detenencias en aquella tierra, causadas de enemigos que $/{ }^{4}$ allí vinieron y otros ynpedimentos que Dios fue servido de dar $/ 5$ me, que él save que yo de mi parte puse toda diligencia por llegar a este puerto. /o En el último auiso que enbié a V. Magestad del Río Genero dixe me deter- /7 minaua a benir por tierra a estas provincias; falto ya de embarcación y $/{ }^{8}$ remedio, y deseoso de servir a Dios y a V. Magestad, como lo yntenté lo yçe (sic). /9 Salí del Río Genero sesenta leguas por la mar hasta el puerto de la $/ 10$ villa de Sanctus, de donde entré la tierra adentro hasta la uilla ${ }^{11}$ de San Pablo. Suplico a V. Magestad mire con atención desde aquí lo que /12 le voy diciendo y oyrá desta gente de San Pablo y su jurisdición / 13 las mayores maldades, trayciones y vellaquerías que le hazen ni $/{ }^{14}$ an hecho vasallos suyos. También oyrá desta tierra donde e lle- / ${ }^{15}$ gado por su governador las mayores lástimas de pobresa y deznudez, / ${ }^{16}$ y poco govierno, poco amparo en las cosas de Dios y ninguna ayuda $/{ }^{17}$ en el vno ni en el otro. En la villa de San Pablo reciden quatro- $/{ }^{18}$ cientos vezinos (sic); tienen sus casas en ella, su asistencia dellos, mu- / ${ }^{19}$ geres y hijos es en los campos; vienen al pueblo los días de fiesta $/ 20$ y esos armados con escopetas, rodelas y fistolas. Públicamente consi- /21 éntenlo las justicias, porque no lo son más que en la aparencias y son / 22 como los demás: muertes, cuchilladas y otras ynsolencias, matán- / ${ }^{23}$ dose y aguardándose en los caminos; todos los días suseden sin que / ${ }^{24}$ aya sido castigado hombre ninguno hasta el día de oy, ni tal se / 25 save; y para que V. Magestad remedie esto y castigue tan malos basallos, no /26 solamente lo son en su patria, sino también en estas prouincias, que bienen / 27 a ellas muchas vezes ducientas y trecientas leguas y se lleban los yndios / 28 reducidos a $V$. Magestad y los que no lo están de aquestos pueblos, y vna / ${ }^{29}$ vez destas llegaron a vno, no estando aý el padre que dotrinaua / /30 los yndios, y se los lleuaron todos con hijos y mugeres, y las ymágenes [de la] / ${ }^{31}$ yglecia, y después la quemaron y a todas las casas. Lo que hazen de to[das] / 32 estas almas que lleuan, christianos y no christianos, es vendellos por e[s]- / ${ }^{33}$ clauos públicamente, y no fuera tanto si se quedaran en la tierra, pe[ro] / ${ }^{34}$ embíanlos en los nauíos a bender por todo el Estado del Bracil y 
$/ 35$ a Lisboa y a otras partes, y aora actualmente estando yo allí y hart[o] /36 temeroso que no me matasen, porque sauían el zelo con que benía a [es-] /37 torbarles algunas cosas, estavan en campo nobecientos hombre[s] / ${ }^{38}$ de aquella villa y su jurisdición con tres mil yndios para b[e]- / ${ }^{39}$ nir azia estas partes a saltear y rovar estas Reduciones, que / ${ }^{40}$ ansí me lo dixeron ellos mesmos. V. Magestad, por quien es y por Dios nuestro señor, pri- $/{ }^{41}$ meramente remedie esto y haga castigar estos traydores que aún no lo son /42 sólo en lo que e dicho, sino también en lo que hazen, y es que para salir en ca[m]- / ${ }^{43}$ po a hazer estas bellaquerías ellos mesmos se hazen capitan[es], /44 alférez y sargentos, y alsan banderas y tocan caxas sin consentimiento /45 de su governador, que digo mal, que lo save y no lo remedia. Esto pasa en / 46 esta villa, cierto y verdadero, porque hablo a $V$. Magestad lo que vy no lo qu[e] / ${ }^{47}$ oý, y quedo corto por no selle molesto, y quien tiene la culpa de que [es-] / ${ }^{48}$ ta ladronera y capa de todos los delinqüentes del Bracil y de Lisb[oa] / ${ }^{49}$ esté como está son los governadores generales de aquel Estado, que a[n] /50 tenido y tienen hasta agora su parte de lo que aquellos traidores roben $/^{51}$ de piesas de yndios e yndias, con que les tapan la boca para que no se les en- $/ 52$ bíen el castigo que meresen y también es causa desta desorden sus mes- $/ 53$ mas justiçias, que son los capitanes y los que los acaudillan. Para ello / $/ 54$ salí con toda priesa de aquella mala tierra por ver si puedo reme- $/ 55$ diar alguna cosa defendiendo estos pueblos de yndios de aquellos tray- $/ 56$ dores con mi presencia y buenos medios, o lo que pudiere hazer si no $/ 57$ quisieren boluerse. Caminé quarenta leguas por tierra y a pie, por ser $/ 58$ camino que no se puede andar de otra manera. Con ynfinitos trauajos de /59 llubias y ríos que pasamos, llegué a vno donde estube vn mes haciendo $/ 00$ embarcaciones de palos grandícimos. Hize tres y la en que (sic) yo benía fue $/{ }^{61}$ de vn palo que tenía ocho brasas de ruedo; bino a quedar después / 62 de labrado güeco por dentro y hecho a modo de vn gran barco, luen- $/{ }^{63}$ go de setenta y cinco palmos de largo y seys palmos de boca. Bení- / ${ }^{64}$ amos dentro della (sic) cinqüenta indios que remauan y mi persona $/{ }^{65}$ y criados. Los otros dos eran la mitad menos, donde benía el susten106 to nuestro y de los yndios. Salí de aquel puesto y caminé por aquel /67 río treinta y dos días con grandícimos riesgos, cada vno de perder- $/{ }^{68}$ me con sus grandes corrientes y saltos que haze el agua en muchas par- $/{ }^{69}$ tes. Andube ocho días por el río grande de La Plata, donde entré /70 por estotro. Aý embío a V. Magestad todo aquel río que andube y lo que e $/{ }^{71}$ andado de éste hasta llegar a este Guayrá, en un borrón que bine $/ 72$ haciendo con tintas de yeruas. V. Magestad lo vea y como tan christianísimo, / ${ }^{73}$ oyga lo que le boy diciendo de esta tierra donde me hallo. Entré / / $/ 74$ en esta Ciudad Real de Guayrá, fui a la Uilla Rica y a la ciudad de Xerez, /75 fui al puesto de Maracayú, donde se coxe y haze la yerua, trato con que $/ 76$ tienen algún refrigerio para ayuda a pasar sus 
grandísimos trauajos /77 los moradores destas ciudades: adbiértole a V. Magestad que diciéndole $/{ }^{78}$ de una le digo de todas las que le e nombrado. En la primera que entré /79 fue menester, por aberme de receuir, dar yo de lo que traýa algunas $/ 80$ cosas menesterosas. Los alcaldes y regidores y demás moradores $/ 81$ desta tierra venían vestidos de lienço de algodón teñido negro, /82 y esto muy roło. Las mugeres [e] hijos destos andan bestidos de lo mes- / ${ }^{83} \mathrm{mo}$; hasta las camisas, con tanta miseria y desbentura que las más $/ 84$ y ellos no la traen. Su sustento son vnas rayçes que se llaman yucas, / 85 naranjas y plántanos y trigo de las Yndias. No tienen bacas ni obe- $/{ }^{86}$ xas ni otro ningún ganado. La tierra en sí es capax (sic) de criar todo $/{ }^{87}$ lo que en España; a les faltado la ayuda para que aquesto fuera a más y que no /88 ubieran pasado tantos trauajos estos pobres, y estas ciudades lo fueran, / ${ }^{89}$ que cierto más son cortijos, y es que después que V. Magestad las pobló y puso /90 debaxo de su proteción y amparo, y sus naturales no an entrado $/ 91$ ni bisitádolas ningún governador ni obispo de los que aquí lo an sido, y ansí $/ 92$ pasan lo que digo. Y es de manera que todos los nacidos en aquella / 93 tierra no están confirmados y en la ciudad de Xerez á años, y mu- $/ 94$ chos, que no tienen vicario ni quien les administren los sacramentos $/{ }^{95}$ y en esta en que me hallo, lo mesmo. ¡Lástima grandísima que biuan $/ 96$ los españoles y sus basallos de V. Magestad como bárvaros! ¡Nobenta y tan- $/{ }^{97}$ tos años que a que se pobló esto y no le ayan dicho la verdad para $/{ }^{98}$ que lo remediase! Prometo a V. Magestad que le estoy escriviendo lastima- / 99 dícimo de ber a estos pobres y su miseria. Sus casas son de xitanos, / 100 que lo digo todo con esto; para darme a mí de comer aún no lo an te- $/{ }^{101}$ nido, y así estoy ayudándoles a su nesecidad. Espero en Dios y en $/{ }^{102}$ el fauor y ayuda de V. Magestad [para] lebantalle estas ciudades y ponérselas $/{ }^{103}$ de manera que bayan a más y estos pobres tengan algún descanso, /104 porque hasta aquí a auido grandes bellaquerías, que, estando /105 bien aberiguadas, las sabrá V. Magestad y también mi cuydado. Suplí- / ${ }^{106}$ cole me ayude, fauoresca y ampare para que le buelua esto a el estado /107 que V. Magestad quiere y yo deseo, mandando a su Real Audiencia de Chu-/108 quisaca me ampare con justicia en todo lo que le pidiere para hazer lo que /109 digo. Dé V. Magestad por bien empleadas mis largas detenencias, que yo /110 doy a nuestro Señor muchas gracias de abérmelas dado, porque espero ha- / 111 celle vn gran servicio y a V. Magestad en aquesta tierra mientras viviere / $112 \circ$ V. Magestad me mandare otra cosa, y entiendo como christiano que $/ 113$ quiso siempre Dios nuestro Señor hiciese yo este camino para su sancto ser[uicio]. / 114 Entrando por esta Ciudad Real de Guayrá comensaron los hombr[es], /115 las mugeres y niños, derramando muchas lágrimas de conte[nto], // 116 a dezirse vnos a otros a vozes: "iAlegría, que ya a benido el reden- / 117 tor de nuestros trauajos y desbenturas!" 
El del cielo y de la tierra me $/ 118$ dé fuerças para que sirua a V. Magestad y en su real nombre ampare $/ 119$ todo aquesto y lo fauoresca. Con esta va vn testimonio del día que /120 tomé la posessión. Suplico a V. Magestad desde ese mesmo me corra el tiempo / $/ 21$ de los cinco años para que en ellos haga lo que tengo dicho hasta don- $/ 122$ de alcansaren mis fuerças con estos pobres, que prometo a $\mathrm{V}$. Magestad / 123 que casi todos los salarios que se me an de dar en este tiempo los estoy $/{ }^{124}$ ya deviendo con los grandes gastos que e tenido y ganancias que /125 me an llebado los que me an dado su dinero en la ciudad del Río Ge- / 126 nero. A los ocho días que allí llegué, casé con doña Vitoria de Saa, hija / ${ }^{127}$ del capitán de aquella fortaleça, Gonsalo de Saa, hermano del governador / ${ }^{28}$ Martín de Saa, hijos del governador y poblador que fue de aquel Río Genero, / 129 Saluador Correa de Saa. No estube con mi muger más que solos / 130 veinte días, y por acudir a esto con toda breuedad y también por / 131 no entrar haciendo descami[nos] y siempre haciéndolos muy / 132 buenos, guardando las órdenes de V. Magestad; la dexé hasta que me en- / 133 víe su lisencia para que benga con su casa y criados por donde yo bine. / 134 Suplícoselo a V. Magestad vmílmente se la dé, para que yo y ella estemos co- $/{ }^{135}$ mo Dios manda, sirbiéndole y a V. Magestad; en tomando la residen- / ${ }^{136}$ cia la despacharé con cuydado, así como V. Magestad manda, y con ella $/{ }^{137}$ todo lo más que se ofresiere abisar del real servicio de $V$. Magestad, / ${ }^{138}$ que guarde Dios felisísimos años para que ampare sus reynos. / 139 Ciudad Real de Guayrá, 8 de nobiembre, 1628 años. $/ 140$ Don Luis de Cés /141 pedes Xería / ${ }^{141}$ (rubrica)

\section{Comentários}

Variantes da primeira carta ${ }^{77}$ com relação a esta segunda

Indica-se a seguir, por grupos, as variantes da grafia da primeira carta com relação a esta (indicada como 2 ou bis), e a linha em que ocorre. $\bigcirc$ leitor consultando a linha indicada encontrará com facilidade a mesma palavra na grafia da segunda carta. Quando necessário indicamos também a palavra modificada na segunda carta, junto com sua grafia na primeira (em itálico), separadas por uma barra.

a. Troca de $v$ (ou u) por b: abiso (6), lleban (32), vellaquerías (43), benían (81), debiendo (124), embie (132-133). 
b. Troca de b por v (ou u): vender (34), Vracil (34), Lisvoa (35), venir (3839), vanderas (44), vino (61), Veníamos (64-65), venía (65), adviértole (77), vestidos (82), desventura (83), visitádolas (91), ver (99), vellaquerías (104), averiguadas (105), avérmelas (1 10), venido (1 16), desuenturas (1 17), lleuado (125), vreuedad (130), venga (133)

c. Troca de c por s: grandísimos (60), sinqüenta (64), grandísimos (67), nasidos (92), lastimadísimos (98-99)

d. Troca de i por x: cortixos (89)

e. Troca de $x$ por i: jitanos (99)

f. Emprego de duplo no início da palavra: rrodelas (20), rregidores (80)

g. Emprego de r simples no meio da palavra: corientes (sic, 68), borrón / borón (sic, 71)

h. Troca de palavras e variantes: causadas / causada (sic, 3), yçe (sic) / hiçe (8), vezinos (sic) / soldados (18), aparencias / aperencia (sic, 21), mil / mill (sic, 38), azia / haçia (39), vy / bi (46), en-bien / embién (sic, 51-52), también / tanbién (sic, 52), justiçias (sic) / josticias (sic, 53), aquella / aquesta (54), los otros (sic) / las otras (65), con / por (68), como / y luego, como (72), los / lo (sic, 91), justicia / josticia (sic, 108), hacelle / hazelle (1 10-1 1 1), dezirse / decirse (1 16), fortaleça / fortaleza (127), Céspedes / Céspedes (140)

i. Acréscimos de textos: na carta 1 faltam todas as palavras: traidores roben de piesas de yndios e yndias, con que $(50,51)$; na carta 1, antes de hombres, existe a palavra yndios, tachada (1 14), na carta 1, a seguinte expressão em itálico está invertida na frase: desde ese mesmo tiempo me corra los cinco años para (120-121).

Balanço geral das diferenças

Parece-nos que as diferenças são relativamente pequenas, e as cartas são essencialmente a mesma, ainda mais por na época não haver uma ortografia oficial, sendo as diversas variantes permitidas.

Sendo escritas ao ditado, o som das letras era idêntico ( $x$ e j, b e v). A letra das duas cartas é muito similar, e os especialistas apontam como sendo de um mesmo autor e provavelmente de um mesmo amanuense, que obrigatoriamente acompanhava o novo governador desde sua saída da Espanha: todos esses cargos deviam ter o apoio de um escrivão para facilitar a comunicação com a coroa. Assim, a carta, na realidade uma relação cronística com estilo epistolar, teria sido ditada pelo próprio 
Céspedes Xeria, pois um amanuense não teria utilizado a linguagem afetiva e familiar do texto, linguagem que pertence portanto ao governador viajante.

As cartas estão condicionadas pela nova realidade encontrada pelo governador; por exemplo, o escasso número de espanhóis fá-lo colocar espontaneamente yndios, logo a seguir corrigido para hombres.

A carta 1 possui um sobrescrito, disposto transversalmente na margem esquerda da última folha, e o texto não iria diretamente às mãos do monarca, mas ao Conselho das Índias, que governava as Indias de Castela.

A carta 2 parece escrita com mais calma e sossego, corrigindo a primeira em alguns pontos: vecinos em vez de soldados é um caso flagrante; o viajante, diante da visão de São Paulo, pensou em seus habitantes. Vecinos eram as casas habitadas, e para se chegar à população seria necessário multiplicar por cinco ou seis o número de casas. Não se tratava, portanto, de soldados, o que foi corrigido na carta 2. Em todo caso parece um exagero, pois na época falava-se de São Paulo como constituída de 120 fogos portugueses, muito menos que os quatrocentos vizinhos dessa carta (linhas 17 e 18). Também é um exagero e incompatível com tais dados quantificar em novecentos soldados os participantes da expedição preadora de Raposo Tavares.

Nessa mesma versão exprime-se de maneira mais precisa alguns aspectos importantes da mensagem do governador: a) as palavras acrescentadas traidores roben de piezas de yndios e yndias con que (linhas 50-51), faltantes na carta 1, em si não eram necessárias, pois a acusação de suborno (dos governadores do Brasil pelos escravocratas) ficava clara na carta 1. Mas a passagem introduzida qualifica (traidores) e especifica a matéria do suborno: tapava-se a boca dos governadores com índios capturados nas correrias paulistas, o que agravava uma corrupção baseada no tráfico escravista contrário às leis espanholas e portuguesas. b) A mudança de desde ese mesmo (día) me corra el tiempo de los cinco años (linha 121 ) busca precisar ao máximo a duração que devia ter esse governo, na realidade pouco prazerosa para Céspedes Xería.

Com esses retoques, a carta 2 fica mais favorável aos interesses de Céspedes e indica que houve uma releitura muito cuidadosa da carta 1 antes de fazer a segunda, como mostram também as correções realizadas: aperencia / aparência; josticia / justicia, além de outras como o uso de rr no meio da palavra e não no início: rodelas, borrón, corrientes, de uso mais aceito na época e o uso mais intenso do b, que dá uma aparência mais culta, mais humanística.

Finalmente, nota-se um amanuense seseoso, pois confundia s, c, z em ambas as direções. Atinha-se ao fundamental, e os deslizes the são naturais na 
operação de escrever ao ditado. Isso confirma que uma mesma pessoa não tinha uma grafia única para a mesma palavra, inclusive ocorrendo variantes de uma mesma palavra no mesmo documento.

O que se pode deduzir desse texto

Frago Gracia (1995), analisando a carta 1, deduz que não se trata de um autógrafo, pela assinatura: nenhum fidalgo ou nobre se dirigia ao rei colocando seu título (Don, ou seja, cavaleiro, fidalgo); já um amanuense, colocando ao final o nome de seu senhor, deveria incluir o título. Mas trata-se de um texto original, muito bem cuidado, com duas únicas correções lyndios, tachado, e a inicial da palavra Reall) e, comparado com outros documentos de época, conclui-se que o documento foi escrupulosamente revisado pelo autor; isso fica claro ao considerar que se tratava da primeira carta do novo governador, escrita já em seus domínios.

Por meio das análises linguísticas e do uso de certas expressões, deduz-se pelos rasgos grafêmicos e morfológicos que se trata de um autor culto. Isso se confirma do ponto de vista estilístico, pelo recurso a orações exclamativas, pelo reforço adverbial em certas expressões e pelo emprego de três elementos nominais consecutivos, conferindo beleza à redação, em mais de dez passagens.

Outra dedução importante é o andaluzismo fonético, decorrente das trocas de s, c e z, em um sentido ou outro (seseo, ceceo), o que denota a origem de seu autor, fato confirmado também pelo emprego de x por $j$. Muitas outras análises linguísticas e terminológicas interessantes podem ser encontradas nesse artigo de referência, a exemplo da assimilação do termo cachuera (cachoeira).

Ao final, discutem-se brevemente alguns aspectos históricos, sendo relevantes os dados populacionais: Assunção (650 vecinos), Guairá (toda a província, 200 vecinos), São Paulo (400 vecinos, o que parece um exagero, como apontamos). Para calcular a população total seria preciso multiplicar esses números por cinco ou seis pessoas. Destaca-se também a confirmação de que essa região dependia da audiência da assim chamada cidade dos quatro nomes: Plata, Charcas, Chuquisaca e modernamente Sucre. Os documentos no Archivo General de Indias estão no item "Audiencia de Charcas".

Todas essas conclusões aplicam-se à carta que transcrevemos, por serem as duas muito semelhantes e ditadas pelo mesmo autor e escritas pelo mesmo amanuense, como se vê pela grafia. 
78. ES.41091.AGI/27.3// MP-BUENOS_AIRES,17BIS.

79. ES.41091.AGI/27.3// MP-BUENOS_AIRES,17.

\section{Apresentação}

Trata-se da transcrição da legenda do Mapa de Céspedes Xeria, na versão do mapa $17 \mathrm{bis},{ }^{78}$ ao final comparada com a do mapa $17 .{ }^{79}$ Os dizeres estão dispostos em três colunas e há uma tabela ao final com a interpretação dos rios.

\section{Notas técnicas da transcrição}

a) $\bigcirc$ caractere '/' marca quebra de linha no texto original e '//' indica mudança de coluna na legenda.

b) Por falta de caractere no teclado, a letra 'y' aparece aqui grafada sem o ponto sobre ela que havia na grafia original.

c) (sic) indica trecho grafado tal qual aparece no documento.

d) Não consignamos pequenas diferenças como letra maiúscula ou minúscula.

e) Em itálico, após a palavra, e entre colchetes, figura a variante da legenda do mapa 1 com relação a este.

\section{Legenda do Mapa de Céspedes Xeria}

Mapa 2 (ou 17bis): apenso à carta 2: Mapa del río Ayembí (actual Tieté) y del Paraná, con sus afluentes, que recorrió Luis de Céspedes Jería, gobernador del Paraguay, al entrar en su jurisdicción desde Brasil. ${ }^{80}$

A. Salto, que haze el río, por nombre caçhuera que cae de al- /2 tísimos riscos y peñascos por cuia caussa nos vinimos [binimos] / $/ 3$ a embarcar abájo [abaxo] dél, caminando por tierra y a pie $/{ }^{4}$ quarenta léguas, camino fragossíssimo [fragosíssimo] con un río $/ 5$ que le pasamos diez y ocho vezes; $/ 0$
80. Transcrição da legenda do objeto cartográfico identificado como ES.41091.AGI/27.3//MPBUENOS_AIRES, 17BIS, guardado no Archivo General de Indias, o mesmo copiado pelo $\mathrm{Eng}^{\circ}$. Santiago Monteiro Dias a mando de Affonso d'Escragnole Taunay em 1917. Também é interessante observar que na descrição documental, o arquivista informa que este mapa está relacionado à correspondência enviada por Céspedes Xeria, governador do Paraguai, datada de 8 de novembro de 1628. Cota: CHARCAS 30 R.1, N.1. 
81. Equivale à negativa "[no] ay raya...".

82. Falta a preposição "por" na carta 1.
- Declaración dél río -

- Las rayas que le atraviesan son todas grandíssimas [grandícimas] /7 corrientes que pasé con las canoas con grandes riesgos. $/ 8$

- Los puntos negros son riscos y peñascos que están $/{ }^{9}$ en mitad de el río, donde peligramos muchas $/{ }^{10}$ vezes. Las [La (sic)] Oes grandes de color amarilla son las / $/ 1$ yslas por donde pasamos, que en todas las más tenía- $/{ }^{12}$ mos grandes corrientes; y estas solas son las parti- $/{ }^{13}$ culares que no ubiera donde pintar, tantas como $/{ }^{14}$ ay. Adviertase que en todo el río ay ${ }^{81}$ raya ni punto $/{ }^{15}$ supérfluo, sino la verdad. Donde se hallare cruz [cruzes] $/{ }^{16}$ es el alojamiento de cadal (sic) dia y la raya bermeja [vermeja] $/{ }^{17}$ que va [ba] por medio del río es [por] ${ }^{82}$ donde camináuamos [caminábamos] $/{ }^{18}$ con las canoas procurando saluar los peligros. $/ 19$

B. Donde esta la b es el puerto que le puse por nombre /20 Nuestra Señora de Atocha donde estuve [estube] un mes con / 21 cinqüenta yndios y mis criados haziendo tres ca- / ${ }^{22}$ noas para salir de allí. La primera que se hizo fue $/{ }^{23}$ de un palo que derrivamos, que tenia de ruedo /24 ocho brasas; labrámosle y vino a quedar una $/ 25$ canoa que tenia setenta y cinco palmos de largo y $/ 26$ seis de voca, en que veníamos [beníamos] por este río cinqüenta $/ 27$ yndios y mi persona y criados. Las otras dos, tenia / 28 una sesenta y seis palmos y quatro de voca, y la outra / ${ }^{29}$ cinqüenta y cinco palmos, y tres y medio [media (sic)] de voca. $/ 30$ Traían estas dos la ropa y matalotaje [matalotaxe] de todos. / ${ }^{31}$

C. En la C tuvimos [tubimos] una peligrosíssima [peligrosísima] corriente; $/ 32$ segundo día de nuestra biaje [biaxe] que nos obligó a salir / ${ }^{33}[a]$ todos por tierra arresgando toda la ropa y comi- / $/ 34$ da, por no poder hazer otra cossa. /35

D. En la $d$ es un peligroso salto que haze allá [allí el agua, $/{ }^{36}$ donde sacamos la ropa en tierra, y las $/{ }^{37}$ canoas las echamos por él, a riesgo de ha- $/ 38$ zerse mill pedaços entre aquellas peñas. /39

x - En el río Sapoy está una hacienda de San Pablo / ${ }^{40}$ por donde bajan [baxan] canoas a este río./ ${ }^{41}$ 
E. En la $\mathrm{E}$, es paraje [parage] donde haze el río grandíssimas [grandísimas] $/ 42$ corrientes. $/ 43$

F. En la f es un gran salto que haze el río por sima / ${ }^{44}$ de grandíssimas [grandísimas] peñas, por cuya causa sacamos las $/{ }^{45}$ canoas por tierra, por ser impusible (sic) [inposible (sic)] yr por el río /46 y se bajaron [baxaron] dos mil pasos. Su nombre proprio es / ${ }^{47}$ Abayandaua, donde se nos atrabesó una canoa / entre dos peñas después de averla [aberla] barado [baxado] / ${ }^{48}$ los dichos pasos sin ser poderoso a poderla / ${ }^{49}$ sacar con cinqüenta yndios. Y todos los que veníamos $/ 50$ acomodámonos lo mejor que pudimos. $/ / 51$

g. En la g. es un salto trabajosíssimo [trauajosíssimo], adonde sacamos $/ 52$ toda la ropa y comida para la poner fuera de riesgo. /53

H. En la h, es un salto peligrossimo (sic) [peligrosimo (sic)] donde sacamos de las ca- / 54 noas la ropa y comida per (sic) sima de peñascos y corrientes /55 más de media legua, y adviértase que desde el salto gran- /56 de Abayandaua hasta aqueste de Ytapira, todo es $/ 57$ grandíssimas [grandícimas] corrientes, peñascos y riscos por donde / 58 veníamos todos los días desnudos, arrenpujando [arrenpuxando] las $/ 59$ canoas y teniéndolas para que no se haziessen [haciesen] pedasos [pedaços] / 100 y otras vezes echándolas al água con palancas. /61

y. Es un gran salto que haze el río por ssima (sic) [sima] de peñascos /62 por cuya causa se sacaron las canoas obra de mill / $/ 63$ y quiñentos pasos. $/ 64$

I. En la l es el fin del río Ayemby, y adonde entra en el / ${ }^{05}$ río de la Plata, en la barra [uarra] del qual están, junto a una ysla, grandísimos remolinos de água y de mucho peligro / ${ }^{60}$ para las canoas, donde me desembarque con toda mi gente, / ${ }^{67}$ siendo [yendo] por tierra gran pedaço, y las canoas por este peligro. 108 Caminamos por este río de la Plata seis días [díaz] con felix (sic) / 69 viaje [biaje] por ser limpísimo [limpiysimo (sic)] todo, hasta el río donde /70

$\{M$.$\} está la m,^{83}$ que es [un río] muy grande, donde tiene Su Magestad / $/{ }^{71}$ dos grandes pueblos de yndios, que abra en ellos, en- / 72 tre hombres, mugerez [mugeres] e hijos, doze [doçe] mill almas. Do- / ${ }^{73}$ trinánlos los padres de la Compañia, jurisdición de $/ 74$ mi gobierno. A la qual barra llegué dia de Nuestra $/^{75}$ Señora de setiembre [septiembre] que fue en el que reenaci (sic) [renaci] $/^{76}$
83. A letra ' $m$ ', caso único no presente documento, não inicia um parágrafo, mas está ao lado dele, e representa o rio Paranapanema, onde se situam as referidas aldeias. 
vautisandome [bauptisandome] mis padres. De aquí navegué por / 77 el mismo río de la Plata ocho días hasta lle- $/ 78$ gar a la Ciudad Real de Guairá donde fui receuido / 79 por governador y capitán general como Su Magestad /80 manda. $/ 81$

N. En la $\mathrm{N}$ es un salto grandíssimo grandícimo que haze el /82 dicho río de la Plata que siendo de legua y media /83 de ancho ba [va] angostandose hasta venir a ser $/{ }^{84}$ de modo que se puede arrojar [arroxar] de una parte $/ 85$ a otra una piedra. Y es tal [tanto] el ruído que $/ 86$ haze que, estando la Ciudad Real de Guayrá / 87 tres leguas y media, se oye en ella como si estu- / ${ }^{88}$ vieran [estubieran] debajo [debaxo] dél. /89

Y. Todos estos riesgos que aquí digo que tuvimos $/ 90$ son por maior [mayor], que no quiero poner los tron- $/{ }^{91}$ pesones que veníamos dando cada ora. $/{ }^{92} \mathrm{Y}$ es cierto que la Virgen Sanctísima de Ato- /93 cha de quien yo soy muy deuoto, y todos / 94 lo fueron en esta ocasión, nos sacó dellos mi- / 95 lagrosamente y así lo tengo por fé porque $/ 96$ conmigo en el discurso de mi vida a he- $/{ }^{97}$ cho tres milagros patentíssimos [patentísimos], dándome /98 muchas ayudas en mis nesesidades [nesecidades]. //99

Tiene este río, por donde veníamos [venimos] hasta entrar / 100 en el de la Plata, tanta abundancia de pes- $/ 101$ cado, dorados y otros géneros que quando / 102 llegáuamos al alojamiento [aloxamiento] se llenaua / 103 tanto cogido coxido a ansuelo que comíamos todos y sobraba sobraua por ay. /104 También tiene grandíssima [grandísima] suma de cassa (sic) [casa], / 105 muchos tigres, leones, muchísimas antas / 106 que matamos, con que veníamos [beníamos] comiendo /107 carne, por ser como de baca, mucha pajarerias [paxareria] / 108 de diversos [diversos] colores. $/ 109$

La interpretación [ynterpretación] de los dichos ríos

Ayemby

Ytamiriguaçu [ytamiriguasu]

Mboy, ry quiere dezir río de unas aves añimas

Río de piedras (chicas y grandes)

Río de las qüentas 
Riviera

Capibary

Y, roy

Sarapoy

$Y$,equacatu

Mbaguarigueen [mbaguariguen]

Yacarey

Piray

Mba,e,y,ry

Camajiboca [camajivoca] Río de las camajibas [camajiuas] de que hazen frechas [flechas]

Yacarepepi

Guacuri y

$Y$, pitanga

Tayaguapoy

Guiray

Aguape y

Paranapane

Miney

Hu y bay

Piquery

Ygatemi
Arroyuelo

Río de las capibaras

Río frio

Río de un peje pexe llamado Sarapó

Río sin peligro

Vomitado de un pájaro [páxaro]

Río de largatos

Río de pejes [pexes]

Río capax de alojamento [aloxamento]

Pestaña de lagarto

Río de unas palmeras

Río colorado

Río de onzas [onças] Río de pájaros [páxaros] Río de hojas [ojas] Río sin pescado Río que no corre Río de cañas Río de las mojarras [moxaras] Río de proa aguda

\section{Comentários}

Variantes da legenda do mapa $7^{84} \mathrm{com}$ relação a esta

Comparando os dois documentos, encontram-se as seguintes variantes da legenda do mapa 17 com relação a esta, que se refere ao mapa 17 bis. Indica-se a linha onde ocorre: 
a. Troca de u ou v por v ou b: binimos (2), ba (17), caminábamos (17), estube (2), tuvimos (31), aberla (49), bauptisandome (76), va (83), estuvieran (88), diversos (108).

b. Troca de b por v ou u: bermeja (16), trauajosíssimo (51), varra (65), viaje (69), camaiivas (tabela).

c. Troca de i por x: abaxo (3), matalotaxe (30), biaxe (32), baxan (40), baxaron (46), arrenpuxando (58), moxaras (tabela).

d. Troca de i por g ou por x: parage (40), arroxar (84), debaxo (88), aloxamiento (102), paxareria (107), páxaro (tabela), pexes (tabela), aloxamento (tabela), páxaros (tabela).

e. Troca de i por y: mayor (90), ynterpretación (tabela).

f. Troca de ss por s ou c: fragosíssimo (4), grandíssimas (6), peligrosísima (31), grandísimas (41 e 44), peligrosimo (sic, 53), grandícimas (57), haciesen (59), patentísimos (97), nesecidades (98), casa (104). (72),

g. Troca de z por c, ç ou s, e vice versa: haciesen (59), díaz (68), mugeres

h. Troca de ç por s: ytamiriguasu (tabela), onças (tabela).

i. Variantes: Las / La (sic, 10), cruzes / cruz (15); es donde / es por donde (17), medio / media (sic, 29), a todos / todos (33), allá / alli (35), impusible (sic) / inposible (sic), varado / baxado (47), ssima (sic) / sima (sic, 61), siendo / yendo (67), limpiysimo (sic, 69), doze / doçe (72), setiembre / septiembre (75), reenaci (sic) renaci (75), tal / tanto (85), veníamos / venimos (99), mbaguarigueen / mbaguariguen (tabela), frechas / flechas (tabela), hojas / ojas (tabela).

Nota preliminar

a. Como foi dito em relação às cartas, na época em que foi escrito esse documento, havia grafias mais usuais, mas não havia uma regra obrigatória, de tal maneira que a troca de letras era admitida como normal ou natural - principalmente quando o som era o mesmo: $u, b$ e $;$;,$g$ e $x ;$ i e $y ; s, z, c$ ou $c$, em documentos que foram escritos ao ditado.

b. Essas mudanças de grafia recebem nomes específicos em castelhano (como em português) como sesseísmo, rotacismo, lambdacismo, entre outros, que não são relevantes ao escopo desta pesquisa. 


\section{Considerações gerais}

A maioria das considerações feitas para as cartas vale para essas legendas. Por exemplo, a variedade das grafias das palavras, ainda que haja uma tendência maior para o uso do x e também ao não uso do s duplo.

Com relação à caligrafia, as legendas apresentam diferenças significativas, dando a impressão de que se trata de dois amanuenses diferentes. A segunda parece ter sido escrita pelo amanuense das duas cartas, ainda que com letra menos cuidada (mais apressada) que a desses documentos principais.

Com relação ao léxico há uma diferença significativa entre a carta e a legenda. Na carta, o autor cuida que não haja deslize de termos indígenas ou hispano-americanos, o que seria fácil de ocorrer, pois ele esteve dois anos em contato com os portugueses e diversos meses com os indígenas. Assim, por exemplo, na carta não aparece o termo canoa, de origem tupi, que foi empregado 22 vezes na legenda do mapa, além de outros vocábulos, como anta. E, acima de tudo e inevitável, a tarefa de consignar os nomes dos rios em tupi-guarani.

Os nomes dos rios

Com a ajuda do professor Eduardo Navarro, montamos a seguinte tabela com três colunas: nome no mapa, etimologia e explicação dos étimos.

\begin{tabular}{|c|c|c|}
\hline Nome no mapa & Etimología & Étimos \\
\hline ayemby & Rio das anhumas & anhum(a) + 'y \\
\hline ytamiriguaçu & $\begin{array}{l}\text { Rio grande das } \\
\text { pedras pequenas }\end{array}$ & itá + mirĩ + 'y + -gûasu \\
\hline mboy, ry & Rio das cobras & $\begin{array}{l}\text { mboîla) - cobra + ry - forma com prefixo de relação } \\
\text { r- de y (t, t) (s.) - 1) água; líquido (Fig., Arte, } 75) \text {; } 2) \\
\text { umidade (VLB, I, 154); 3) sumo (ainda na fruta), caldo } \\
\text { (Anch., Arte, 13); 4) rio }\end{array}$ \\
\hline capibary & Rio das capivaras & kapibar(a) +'y \\
\hline y, roy & Água fria & 'y + ro'y \\
\hline sarapoy & Rio dos sarapós & sarapó + 'y \\
\hline y, equacatu & Fontes boas & 'ykûar(a) + katu \\
\hline mbaguariguien & Vômito de maguaris & magûari + gûe'ena \\
\hline
\end{tabular}




\begin{tabular}{|c|c|c|}
\hline yacarey & Rio dos jacarés & îakaré + 'y \\
\hline Piray & Rio dos peixes & pirá + 'y \\
\hline mba'e,yry & $\begin{array}{lr}\text { Depósito } & \text { (lugar } \\
\text { abrigado onde se } \\
\text { podem guardar } \\
\text { coisas e abrigar as } \\
\text { pessoas) }\end{array}$ & $\begin{array}{l}\text { mba'e - coisas + uru - repositório, depósito, } \\
\text { receptáculo, recipiente: depósito de coisas }\end{array}$ \\
\hline camajiboca & Camajibas rachadas & $\begin{array}{l}\text { kamaîyba (s.) - nome de uma planta, uma cana com } \\
\text { nódulos (VLB, I, 65) + bok rachar, romper-se, fender-se, } \\
\text { arregoar (p.ex., o figo); arrebentar (VLB, I, 42): }\end{array}$ \\
\hline yacarepepi & Festa dos jacarés & $\begin{array}{l}\text { îakaré + pepyra - festa ritual (de comer, de beber); } \\
\text { banquete: kaû̃ pepyra - festa de cauim (Staden, } \\
\text { Viagem, 61) }\end{array}$ \\
\hline guacuri y & Rio dos bacuris & $\begin{array}{l}\text { bakori - planta da família das clusiáceas, Platonia } \\
\text { insignis Mart. (Silveira, Relação do Maranhão, fl. } 11 \mathrm{v} \text { ) } \\
+ \text { 'y - rio }\end{array}$ \\
\hline$y$, pitanga & Rio pardo, rio corado & $\begin{array}{l}\text { 'y - rio + pytang - qualquer cor clareada pelo branco; } \\
\text { cor pastel + sufixo -a }\end{array}$ \\
\hline tayaguapoy & Não identificado & \\
\hline gui yay & Rio dos pássaros & gûyrá + 'y \\
\hline aguape y & Rio dos aguapés & agûapé + 'y - rio dos aguapés \\
\hline paranapané & $\begin{array}{l}\text { Rio azarado, rio im- } \\
\text { prestável }\end{array}$ & $\begin{array}{l}\text { paraná - rio (na língua geral paulista) + panem - } \\
\text { azarado; que não tem peixes; ruim para a navegação } \\
\text { por ter muitos meandros etc. + suf. -a }\end{array}$ \\
\hline mi ney & $\begin{array}{l}\text { que não se mexe; } \\
\text { coisa que não se } \\
\text { mexe laparece em } \\
\text { Montoya com este } \\
\text { sentido). Isto é, um } \\
\text { rio parado, com } \\
\text { gradiente } \\
\text { pequeno. }\end{array}$ & $\begin{array}{l}\text { myĩ (v. intr.) - mexer-se, mover-se (VLB, II, 43); bulir-se } \\
+-e^{\prime} y m \text { - sufixo que expressa privação, ausência, falta }\end{array}$ \\
\hline hu y bay & $\begin{array}{l}\text { Rio das ubás, das } \\
\text { canas-ubás }\end{array}$ & $\begin{array}{l}\text { u'ubá - cana-ubá, ubá, cana-de-flecha, planta que } \\
\text { produz canas para flechas, espécie de gramínea + } \\
\text { 'y-rio }\end{array}$ \\
\hline piquiry & $\begin{array}{l}\text { Rio dos peixes } \\
\text { pequenos }\end{array}$ & $\begin{array}{l}\text { pikira* - termo da língua geral paulista que designava } \\
\text { peixe pequeno. (Em Tupi antigo, piky'yra é a irmã mais } \\
\text { nova da mulher.) + 'y - rio }\end{array}$ \\
\hline ygatimi & $\begin{array}{l}\text { Rio das canoas } \\
\text { emproadas }\end{array}$ & $\begin{array}{l}\text { De ygara-canoa + fĩ - proa, ponta + 'y- rio: rio das } \\
\text { canoas emproadas }\end{array}$ \\
\hline
\end{tabular}


Por outro lado, em todo o resto do trajeto, anotam-se pequenos riachos, sem nome próprio. Mais adiante, quando se entra em rio morto (sem corredeiras e outros obstáculos), tudo parece igual.

f. Alguns locais mantiveram o topônimo: Capivari, Avanhandava, Itapura, ou mantiveram o conceito mudando de língua: Piraí, Rio do Peixe. Outros são pouco esclarecedores: há três rios Jacareí e um Jacarepepi, que poderia ser o Jacaré Pepira, se não estivesse na margem contrária.

g. Esse caminhamento foi comparado com as descrições de viagem pelo Tietê de Jusarte e de Hércules Florence, bem como com os mapas da CGG (1905) e do IBGE (1972). Tantos os nomes como as corredeiras e saltos ajudaram na identificação de alguns topônimos. $\bigcirc$ Tietê possui uma bacia estreita na maior parte de seu percurso, de forma que não existem muitos rios caudalosos que seriam candidatos mais prováveis a serem assinalados no mapa, mas isso foi de pouca ajuda.

h. Como resultado identificou-se uma porcentagem razoável dos rios, mas ainda assim diversos cursos d'água não foram identificados, a exemplo dos três primeiros e pequenos afluentes da margem esquerda e alguns mais. Assim foi elaborada a tabela a seguir:

\begin{tabular}{|c|c|c|c|c|}
\hline $\mathrm{N}$ & $\begin{array}{l}\text { Nome junto ao } \\
\text { topônimo }\end{array}$ & $\begin{array}{l}\text { Grafia } \\
\text { atualizada }\end{array}$ & $\begin{array}{l}\text { Interpretação / } \\
\text { nome atual }\end{array}$ & Fundamento / explicação \\
\hline 1 & Rio de Ayembi & Anhembi & Tietê & Vai de São Paulo ao Rio Paraná \\
\hline A & Salto Cachuera & & Salto em ltu & Antes do Porto de Araritaguaba \\
\hline B 1 & $\begin{array}{l}\text { Porto } N^{a} S^{a} \text { de } \\
\text { Atocha }\end{array}$ & & $\begin{array}{l}\text { Araritaguaba / } \\
\text { Porto Feliz }\end{array}$ & $\begin{array}{l}\text { Já havia experiência de } \\
\text { navegação e sobre } 0 \text { melhor } \\
\text { local para embarcar }\end{array}$ \\
\hline El & Mboy ry & Mboy / Embú & (m) Bojui & Grafia e som \\
\hline Dl & Ytamiriguaçu & Itamirimguaçú & & $\begin{array}{l}\text { Três pequenos afluentes da mar- } \\
\text { gem esquerda difíceis de ident- } \\
\text { ficar }\end{array}$ \\
\hline E2 & Rivera & & & \\
\hline E3 & Riveron & & & \\
\hline C & $\begin{array}{l}\text { Corrente muito } \\
\text { perigosa }\end{array}$ & & $\begin{array}{l}\text { Corredeira do } \\
\text { Matias }\end{array}$ & $\begin{array}{l}\text { Imediatamente antes do rio } \\
\text { Capivari }\end{array}$ \\
\hline D2 & Capibary & Capivari & Capivari & Homonímia e posição \\
\hline
\end{tabular}




\begin{tabular}{|c|c|c|c|c|}
\hline D3 & Y roy & Roi? & & $\begin{array}{l}\text { Pequeno afluente não identifica- } \\
\text { do }\end{array}$ \\
\hline E4 & Sarapoy & Sarapuí & $\begin{array}{l}\text { Sarapuí, afluente } \\
\text { que nomeia } \\
\text { Or principal: } \\
\text { Sorocaba }\end{array}$ & $\begin{array}{l}\text { Gente de São Paulo em Soro- } \\
\text { caba }\end{array}$ \\
\hline E5 & Y equacatu & Equacatu & Capivara? & Nasce na serra de Botucatu \\
\hline D4 & mbae y ry & & Piracicaba & $\begin{array}{l}\text { Posição. Pelo caudal não podia } \\
\text { faltar no mapa }\end{array}$ \\
\hline E6 & Mbaguarigueen & & Araquá? & \\
\hline D & Salto perigoso & & Bariri Guaçu & Maior cachoeira no trecho \\
\hline D5 & yacarey & Jacareí & Jacaré Pepira & Posição e Nome \\
\hline$E$ & $\begin{array}{l}\text { Correntes muito } \\
\text { grandes }\end{array}$ & & $\begin{array}{ll}\text { Cachoeira } & \text { Gua- } \\
\text { micanga } & \text { ou } \\
\text { Vamicanga } & \\
\end{array}$ & Posição \\
\hline E7 & Piray & Piraí & Batalha & Posição \\
\hline E8 & Mbauru & & & Não identificado \\
\hline D6 & yacarey & Jacareí & dos Porcos & Posição \\
\hline E9 & Camajiboca & & Batalha & Posição \\
\hline E10 & Yacarepepi $^{2}$ & Jacaré Pepi & Dourado & Posição \\
\hline D7 & Rivera grande & & da Fartura & Posição \\
\hline $\mathrm{F}$ & $\begin{array}{l}\text { Salto de Avan- } \\
\text { handava }\end{array}$ & & & Avanhandava \\
\hline G & Salto trabalhoso & & $\begin{array}{l}\text { Cachoeira das } \\
\text { Ondas Grandes }\end{array}$ & $\begin{array}{l}\text { Maior, dentre as três próximas de } \\
\text { Avanhandava }\end{array}$ \\
\hline D8 & yacarey & Jacareí & & Dois pequenos, não identificados \\
\hline E11 & Riveron & & & \\
\hline $\mathrm{H}$ & Salto & & Itapura mirim & Posição, logo antes \\
\hline I & Salto de Itapura & & Itapura & Homonímia \\
\hline 2 & $\begin{array}{l}\text { Parana que es el } \\
\text { Rio de La Plata }\end{array}$ & & Paraná & Homonímia e Posição \\
\hline D1 & Parnaíba & & Parnaiba & Homonímia e Posição \\
\hline D2 & Cururay & & Pântano & Posição \\
\hline El & Ytayquiri & & $\begin{array}{l}\text { São José dos } \\
\text { Dourados }\end{array}$ & Posição \\
\hline E2 & Ayembi & & Tietê & \\
\hline D3 & guacury y & $\begin{array}{l}\text { Guacuri ou Ba- } \\
\text { curi }\end{array}$ & Sucuriú & Posição \\
\hline E3 & y pitanga & Ipiranga & Feio ou Aguapeí & Posição \\
\hline E4 & tayaguapoy & Taiaguapoí & do Peixe & Posição \\
\hline E5 & guiray & Guiraí & Santo Anastácio & Posição \\
\hline
\end{tabular}




\begin{tabular}{|l|l|l|l|l|}
\hline D4 & aguapey & Aguapeí & Pardo & Posição \\
\hline E6 & paranapane & & Paranapanema & Homonímia e Posição \\
\hline D5 & miney & Minei & Ivinhema & Posição \\
\hline E7 & Hu y bay ${ }^{3}$ & Ivaí & Ivaí & Posição \\
\hline E8 & piquiry & Piqueri & Piqueri & Posição \\
\hline D6 & Ygatimy & lguatemi & lguatemi & Posição \\
\hline
\end{tabular}

Variantes presentes no duplo, ou seja, mapa 17:

1. B / D, por engano, pois é $B$;

2. Existe um Jacaré Pepira, mas na margem direita;

3. Huybay (uma palavra só).

Esclarecimento: o termo "Posição" indicado nessa tabela corresponde à topologia: antes, depois ou em frente na sequência dos afluentes no rio. Existem ainda outros topônimos em posições que não ao longo do Tietê, relacionados na tabela abaixo:

\begin{tabular}{|c|l|l|}
\hline N & \multicolumn{1}{|c|}{ Mapa 17bis } & \multicolumn{1}{c|}{ Mapa 17} \\
\hline T & $\begin{array}{l}\text { Este Rio Andubo D. Luis de Céspedes Xeria } \\
\text { gov.or y cap.an gl.del paraguay }\end{array}$ & $\begin{array}{l}\text { Este Rio andubo D. Luis de céspedes Xeria } \\
\text { gov.or y cap.an gl.del paraguay }\end{array}$ \\
\hline 1 & La villa de san pablo en el Braçil & Villa de S. Pablo / en el Brasil \\
\hline 2 & Aldea de $\mathrm{n}^{a} \mathrm{~s}^{a}$ de loreto / del pirapo & Aldea de $\mathrm{n}^{a} \mathrm{~s}^{a} /$ de loreto \\
\hline 3 & Aldea de S. Ignaçio & Aldea de S. / Ygnaçio \\
\hline 4 & çid Real del guaira & Ciud. Rl. de guaira \\
\hline 5 & çiudad de gerez & Ciud Gerez \\
\hline 6 & Villa rrica & Villa Rica \\
\hline
\end{tabular}

